\title{
A semantic analysis of modal DE 得 in pre-modern Chinese $^{1}$
}

\author{
Barbara Meisterernst \\ bmeisterernst@gmail.com \\ National Tsing Hua University, Taiwan
}

\begin{abstract}
In this paper, the lexical semantics of the pre-modal verb 得 dé and its development into a modal auxiliary will be discussed. Two different positions are available for the modal dé, the default preverbal position of modal auxiliary verbs and a post-verbal position. The analysis of the event and the argument structure of the lexical verb dé reveals that the different modal uses of dé originate from its functions as an achievement verb. In this regard, dé clearly differs from the other verbs of possibility in Late Archaic Chinese. The particular syntacto-semantic constraints of dé can account for its development into both a modal auxiliary verb, and for the particular functions it develops in the Modern Sinitic languages as a postverbal modal marker.
\end{abstract}

Keywords: Lexical semantics, Lexical verb, Modality, Possibility modality, Grammaticalization

\section{Introduction}

In Late Archaic $\left(5^{\text {th }}-2^{\text {rd }} c\right.$. BCE, LAC $)$ and Early Middle Chinese $\left(2^{\text {st }} c . B C E-6^{\text {th }} c . C E\right.$, EMC $)^{2}$, the most important modal auxiliaries expressing POSSIBILITY and ABILITY are 能 néng 'able to', 可 ké 'possible', and 得 dé 'manage to, able to'. The three verbs differ syntactically and etymologically: ké 'be possible', and néng 'be able' are derived from state verbs; dé 'get, obtain, manage to, able to, (must)' on the other hand is derived from an achievement verb. All three modals appear as lexical verbs and as modal auxiliary verbs in Late Archaic Chinese. ${ }^{3}$ The examples (1a-c) represent the lexical employment, and the examples in (1d-f) represent the employment as modal auxiliary verbs.

\footnotetext{
${ }^{1}$ This paper was presented as a keynote address at the $19^{\text {th }}$ CLSW workshop, May 2018 at National Chung Cheng University in Chiayi, Taiwan. I am grateful for the comments of two anonymous reviewers who greatly helped to improve the final version of the paper. All remaining errors are mine.

${ }^{2}$ The $2^{\text {nd }} \mathrm{c}$. BC is traditionally considered the last century of the LAC period, but it can also be considered part of the transition period in which the features of Early Middle Chinese start to develop. According to Peyraube (1996), the period from the $1^{\text {st }} c . B C E-1^{\text {st }} c$. CE is labeled Pre-Medieval, and the period from the $2^{\text {nd }}-6^{\text {th }} c$. CE is labeled Early Medieval Period.

${ }^{3}$ The verb 獲 huò 'catch, capture, manage to do, be able' is very similar in meaning and functions to a verb of possibility in Archaic Chinese (Liu 刘利 2000: 175f). Liu 刘利 points to a similar path of grammaticalization of the two verbs huò and dé. However, huò is much less frequent in its function as an auxiliary verb than dé is. Liu 刘利 provides a comprehensive treatment of the grammaticalization of dé from a lexical verb to a modal verb expressing 'objective conditioned permission 客觀條件許可 kèguān tiáojiàn xǔkě̀' or 'circumstantial permission 事理許可 shilǐ xǔkě.
} 
(1) a. 有無父之國則可也。」(zuǒzhuàn, huán 16.5.3) (LAC)

Yŏu_wú_fù_zhī_guó_zé_kě_yě

Have_not.have_father_GEN_state_then_possible_SFP

If there is a country without fathers, then it is possible.

b. 能信不為人下, 吾未能也。 (zuǒzhuàn, zhāo 1.1.13) (LAC)

Néng_xìn_bù_wéi_rén_xià_wú_wèi_néng_yě

Able_believe__NEG_be_man_below_I_NEG_able_SFP

Those who are able to believe are not below others; I am not able to.

c. 申侯由是得罪。(zuǒzhuàn, xī 5.5.2) (LAC)

Shēn_hóu_yú_shì_dé_zuì

Shen__hou_from_this_get_guilt

Shen hou had become guilty from then on.

d. 「吾不可用也已。」 (zuǒzhuàn, dìng 4) (LAC)

Wú_bù_kě_yòng_yě_yř

I_NEG_KE_employ_SFP_SFP

I cannot be employed [anymore].

e. 夫賢主者, 必且能全道而行督責之術者也。 (shijì: 87, 2554) (EMC)

Fú_xián_zhŭ_zhě__bì_qiě_néng_quán_dào_ér_xíng_dūzé_zhī_shù_z

hě

SIP_virtuous_ruler_NOM_certainly__FUT_NENG_complete_way_CON_ perform_investigate.and.punish.crime_SUB_method__NOM_SFP

$A$ virtuous ruler will certainly be one who is able to guard the right way and thus to perform the method of controlling and punishing criminals.

f. 晉、楚無信, 我焉得有信? 」 (zuǒzhuàn, xuān 11) (LAC)

Jìn_Chǔ_wú_xìn_wǒ_yān__dé_yǒu_xìn

Jin_Chu_not.have_faith_I_how_DE_have_faith

Jin and Chu do not have faith, how can we managel be able to have faith.

The most conspicuous difference between modal DE and the other possibility modals is the postverbal position one of the successors of DE obtains in Modern Mandarin and other Sinitic languages. Two different positions are reported for DE, the preverbal position, identical to the preverbal position in LAC and EMC, and the postverbal position.

Xie (2012) in his study on postverbal DE in Modern Mandarin proposes three different readings of DE, an ability, an opportunity, and a disposition reading. All three readings "have to do with the potential to cause or undergo 'change of state' that is attributable to properties of the subject and/or of the utterance contexts (Hackl 1998; Bhatt 1999)." For an ability reading, represented by (2a), the subject needs to be agentive (Xie 2012: 391). Agency can be tested by the do-test (Cruse 1973), 'John breaks the vase' entails 'John did something', whereas 'the vase broke' does not. Cruse argues that agents can also be inanimate. With a non-agentive unaccusative subject, no ability reading is available (Xie 2012: 391) as in (2b). The same accounts for instrumental subjects and for state verbs preceding DE. These readings are termed dispositional readings in Xie. (2c) is an example for the opportunity reading of DE in a particular temporal setting and (2d) is a typical example for the disposition reading.

(2) a. Zhāngsān_yīgèrén_bān_de_qǔlai_nà_xiāng_shū (Xie 2012: 388) Zhangsan_alone_lift_DE__up_that_box_(CL)_book Zhangsan can lift up that box of books all by himself.

b. dàrén_cóng_xiépō_shàng_huá_de__xiàlái (Xie 2012: 391) adult_from_slope_on__slip__DE_down An adult can slide down from the top of the slope. 
c. Nǐ_zài_wăng_shàng_kàn_de__dào_wǒ_de__shíhòu_wǒ_dōu_xián_zhe You_at_internet_on_see_DE_reached_me_MOD_time_I_all_free_PR OG When(ever) you see me on the internet, I am free. (Xie 2012: 392)

d. zhè_zhǒng_jīqi_yīge_xiăoshí_suì_de_wán_shí_dūn_yùmì this_kind_machine_one_hour_crush_DE_finish_ten_ton This machine can crush ten tons of corn in an hour. (Xie 2012: 392)

Besides postverbal DE, a deontic modal marker DEI, appearing in the regular position of modal auxiliaries exists in Modern Mandarin.

(3) Zhāngsān_jīntiān_děi_qù_kàn_yīshēng (Xie 2012: 396)

Zhangsan_today_must__go_see_doctor

Zhangsan must go see his doctor today.

This syntacto-sematic feature distinguishes modal DE from the other possibility modals and leads to the hypothesis that at least in some of its functions in LAC and EMC, DE rather has to be analyzed as a pre-modal lexical verb than as a fully grammaticalized modal auxiliary. We will argue that this special feature accounts for the particular diachronic development of DE into a postverbal element introducing manner or result. The syntacto-semantic features of dé as an achievement verb account for the particular constraints of dé as an implicative modal verb, basically expressing opportunity. In the following sections, the lexical semantics of the premodal lexical verb dé and its development into two different modal markers will be discussed. In section 2, the argument structure of the lexical verb dé is at issue, mainly based on the framework proposed in Levin (1993), Levin and Rappaport Hovav (1995), and Rappaport Hovav and Levin (1998), despite the problems pointed out in Dölling and Heyde-Zybatow (2007) with this approach. Section 3 is devoted to the different modal readings of DE in LAC and EMC, and section 4 provides a brief introduction to the development of postverbal DE and proposes a possible analysis for this development.

\section{The lexical verb 得 $d e$}

\subsection{The argument structure of dé in Early Archaic and Late Archaic Chinese}

The lexical verb dé can appear as an intransitive, i.e. unaccusative verb, a transitive verb, and in a ditransitive structure introducing an additional argument. Morphologically, the verb dé, EMC $t \cong k$, belongs to the class of verbs of 'receiving' (得到 dédào). These are according to Jin 金理新 (2006: 364f) characterized by the fact that they do not occur in the qùsheng category (idem). The qùshēng is connected to an increase of valency, or to resultative readings. The verbs of receiving to which dé belongs are endodirectional (Mei 梅祖麟 2000, Xing and Schuessler 2020) telic achievement verbs. In the Early Archaic Chinese $\left(10^{\text {th }}-6^{\text {th }}\right.$ c. BCE, EAC) text Shijing, dé is only attested as a lexical verb with the basic meanings 1) (itr.) 'available, obtainable' (TLS proposes an intransitive meaning 'successful') ${ }^{4}$; 2) (tr.) get, obtain, find, catch'. In (4a) dé is transitive, containing a direct object; in (4b) no object appears overtly, the verb is intransitive/unaccusative. For LAC, it has been proposed that a pronominal object can remain empty if the VP is negated (see e.g. Pulleyblank 1995), as in the first clause of example (4b) ( $>>$ 'he does not gain PRO). According to this, it cannot be excluded that dé in this example

\footnotetext{
${ }^{4}$ TLS: http://tls.uni-hd.de/main/basic_ch_text.lasso, accessed 01.10.2018.
} 
is transitive with a covert object pronoun. ${ }^{5}$ In the second clause, no negation is involved. This argues for an intransitive analysis of $d e$ in this clause, and - by way of parallelism of the two instances - for an unaccusative analysis in both instances in (4b), and subsequently also in (4c). In the examples (4d-f) the VPs with dé contain a 于 yú -PP. In (4d), dé appears in a syntactic ditransitive construction, the indirect object is introduced by the preposition 于 $y u ́$; the direct object of dé is zuì 'crime, guilt'. 得罪 dé zuì is frequently attested in a transitive or a ditransitive construction, with an additional indirect object. ${ }^{6}$ The indirect object is not a goal, but rather an affectee in a benefactive (malefactive) construction. In (4e), the direct object is the $w h$-word 胡 $h u$ ' what', the PP 焉 yán, representing $y u ́+3 \mathrm{Obj}$ according to early commentaries, refers to a local complement 'in it'. In (4f), dé again appears in its negated form; in this example, no direct referent for an internal argument seems to be available, accordingly it is understood as intransitive; the PP is locative. In (4g), dé is transitive and passivized in the complement of the possibility modal verb 可 $k e \check{e}$, which requires a transitive/causative complement in a resultative, i.e. unaccusative construction (see e.g. Meisterernst 2008a, 2019a).

(4) a. 燕婉之求, 得此戚施。(shïjīng, guófēng) (EAC)

Yānwăn_zhī_qiú_dé_č̌_qīshī

Pleasant_docile__ $\overline{\mathrm{GEN}}$ __search_get_this_toad

In search of a pleasant and docile one, she found this toad.

b. 罒媒不得。既曰得止, 曷又極止！ (shïjīng, guófēng) (EAC)

Fěi_méi_bù_dé _jì_yuē_dé_zhǐ_hé_yòu_jí_zhř

Is.not_go.between_NEG_zet__already_say_get_SFP_why_again_extreme SFP

Without a go-between, she will not be gained (= you do not succeed). After saying 'she has been gained, why go on to such extremes!

c. 㝥棩求之。求之不得, (shījing, guófēng) (EAC)

Wù_mèi_qiú_zhī._Qiū_zh̄̄_bù_dé

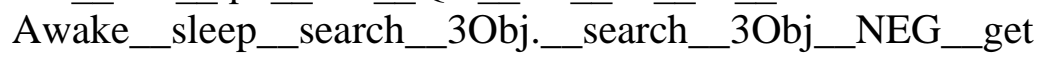

Awake and sleeping he searched for her, he searched for her, but she was not found.

\footnotetext{
${ }^{5}$ According to Djamouri (1991), transitive verbs are typically negated by the negator 弗 fú and not by bù 不. This approach has also been adopted in the present study. The negator fú has attracted a lot of attention in the linguistic debate (see e.g. Djamouri 1991, Pulleyblank 1995, Wei 魏培泉 2001, and references to earlier work therein). One of the hypotheses proposed is that fú is a fusion of bù and the object pronoun 之 $z h \bar{l}$ (supported e.g. in Wei 魏培 泉 2001), based on the fact that the object pronoun is zero when the verb is negated by fú. Pulleyblank (1995), by contrast, proposes an aspectual reading, due to the coda *-t. Additionally, he points out that a Han period taboo on fú might have blurred the picture of its occurrence in the transmitted texts. This taboo may be responsible for the apparent interchangeability of fú and bù in the transmitted Archaic Chinese literature. Aldridge (p.c.) proposes that LAC is not an object pro-drop language; object pro-drop seems to be mostly confined to negated contexts. This contrasts with the earliest attested periods of Chinese, which seem to allow object pro-drop, and with Modern Chinese, which clearly permits object pro-drop. The 3P object pronoun $z h \bar{\imath}$ 之 of LAC is attested only as a demonstrative pronoun in the oracle bone inscriptions; $z h \bar{l}$ as an object pronoun first appears in the bronze inscriptions of the beginning of the Spring and Autumn Period (770 BCE) according to Djamouri (1999). In the Shijing, in Early Archaic Chinese, the object pronoun $z h \bar{\imath}$ is well attested and seems to be obligatory with typical transitive verbs.

${ }^{6}$ In the Thesaurus Linguae Sericae (http://tls.uni-hd.de/, accessed July 23, 2018) three different shades of meaning are listed for this frequent phrase: 1) transitive: 'commit an offense against a contextually determined $\mathrm{N} ; 2$ ) ditransitive: 'fall foul of, commit a crime against N'; in 3) the PP is left out, the indirect object is contextually determined. LAC has two different kinds of ditransitive structures with semantically ditransitive verbs: 1) V IO DO, b) V DO yú 於/于 IO. Morphologically dé belongs to the verbs of receiving, many of which are ditransitive verbs.
} 
d. 云不可使, 得罪于天子; (shījīng, xiǎoyă) (EAC)

Yún_bù_kě_shǐ_dé_zuì_yú_tiānzǐ

Say_NEG__possible__sent_obtain_guilt_PREP_heaven_son

If one refuses to be employed, one becomes guilty (obtains guilt) against the son of heaven.

e. 人之為言, 胡得焉! (shījīing, guófēng) (EAC)

Rén_zhī_wèi_yán_hú_dé_yán

Man_GEN_false__word_what_find_in.3Obj

The people's false words, what can you find in them!

f. 如罒行遇謀, 是用不得于道。(shijjīng, xiăoyă) (EAC)

Rú_fẽi_xíng_mài_móu_shì_yòng_bù_dé_yú_dào

Be.like_NEG__go_proceed_consult_therefore_NEG_get_PREP_road

This is like consulting without moving forward; therefore nothing will be gained on the road.

g. 為鬼為蜮, 則不可得。(shījīng, xiǎoyă) (EAC)

Wéi_guǐ_wéi_yù_zé_bù_kě_dé

$\mathrm{Be}$ _ohost_be_turtle_then_NEG_KE_obtained

If you were a ghost or a turtle, you could not be caught.

In all instances in the Shijing the subject is [+HUMAN], independently of the argument structure of dé, i.e. independently of whether the subject is a theme or a goal argument. The agentivity features of the subject of dé are in all cases very low, if existent at all, although agentivity has been proposed as distinguishing feature for postverbal ability DE according to Xie (2012). The internal argument in a transitive construction can range from [+HUMAN] to [+ABSTRACT]. For an intransitive employment of dé as in (4b), the TLS proposes the meaning 'be successful'. This seems to be a translation derived from the unaccusative alternation 'NP be gained, won, obtained' $>>$ the fact that NP has been obtained implies that subject has succeeded in obtaining the endpoint of the event.

The following argument structure of dé is attested in the Shijing:

a) VP1: NP1[+HUMAN $]_{\text {goal }}$ V NP2 $2_{\text {theme }}[+$ HUMAN $] /[+$ ABSTRACT $] \rightarrow$ transitive

b) VP2: NP1[+HUMAN $]_{\text {theme }} \mathrm{V} \rightarrow$ intransitive

c) VP3: NP1 [+HUMAN] goal V (NP2 theme $_{\text {gú }}$ 于 $-\mathrm{PP} \rightarrow$ (di)transitive, benefactive (malefactive)

d) VP3: NP1[+HUMAN $]_{\text {theme }} \mathrm{V} y u ́$ 于-PP $\rightarrow$ intransitive with locative PP (source)

The set of subjects of the intransitive use [+HUMAN] is a subset of the objects of the transitive use [+HUMAN]/[+ABSTRACT]. According to Levin and Rappaport Hovav (1995: 86), "the asymmetry in the selectional restrictions is significant since it provides a guide to which variant is basic." This seems to imply that the basic use of dé is the transitive use and not the intransitive/unaccusative use. The thematic role of the [+HUMAN] subject in (4a), (4c) and (4d) is the goal of the situation expressed by the predicate; no agent seems to be involved. Since the goal subjects of dé in the Shijing are [+HUMAN], i.e. sentient according to Dowty (1991: 581), and sentiency is a typical Proto-Agent entailment, this may be the distinctive feature that qualifies them as subjects of the verb of getting and receiving dé and allows a grammaticalization to functions requiring an agentive subject. According to the hierarchy of thematic roles in Bresnan (2001: 307, cf. Xiong 2017) goal or experiencer is the lowest of rank of the roles agent, beneficiary and goal; they all precede the roles of instrument and patient/theme though. ${ }^{7}$

\footnotetext{
${ }^{7}$ See also Marelj (2004: 198, cf. Xiong 2017: 48) according to whom goals are [+CAUSE].
} 
All the basic functions of the lexical verb dé are also attested in the Late Archaic Chinese texts Zuǒzhuàn and Guóyü; the auxiliary verb dé is still not very frequent in these texts. The transitive and ditransitive constructions become more frequent, whereas the intransitive construction is extremely infrequent. Examples for the intransitive construction appear in (5a) and (5b). The structure of the two examples is identical. Intransitive dé almost exclusively appears in this structure in the two texts checked. The subject is [-HUMAN/+ABSTRACT] in both examples.

(5) a. 信、禮之亡, 欲免, 得乎? 」 (zuǒzhuàn, chéng 15) (LAC)

Xìn_lì_zhī_wáng_yù_miăn dé_hū

Trustworthiness_propriety_GEN_demise_wish_avoid_gained_SFP/Q

When trustworthiness and propriety perish and one wishes to avoid it, will it be gained (= will one be successful?)

b. 若殺不幸, 將失其民, 欲安, 得乎? (zuǒzhuàn, chéng 15) (LAC)

Ruò_shā_bù_gū_jiāng_shī_qí_mín_yù_ān_dé_hū

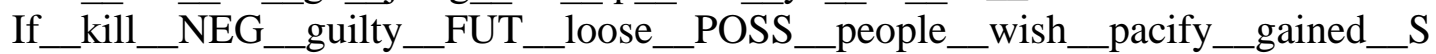
$\mathrm{FP} / \mathrm{Q}$

If he kills the innocent he will lose his people, and if he wants to find peace [then], will it be gained (=will he succeed)?

The examples in (6) all show the transitive employment of dé: in (6a), zuì 'guilt', an abstract noun, appears as the internal argument of $d \dot{e}$; in (6b), the internal argument is also an abstract noun; in (6c), the internal argument is a proper name and [+HUMAN], and in (6d), it is [+HUMAN]. In (6a-c), the goal subject is [+HUMAN], in (6d), it is abstract, referring to the name of the state. However, state names can be used metonymically in order to refer to the ruler of the state. Thus, it can also be considered [+HUMAN].

(6) a. 申侯由是得罪。(zuǒzhuàn, xī 5.5.2) (LAC)

Shēn_hóu_yú_shì_dé_zuì

Shen__hou_from_this__get_guilt

Shen hou had become guilty from then on.

b. 歸之而質其大子, 必得大成。(zuǒzhuàn, xī 15.4.25) (LAC)

Gūî_zhī_ér_zhì_qí_dàiž̌_bì_dé_dà_chéng

Return_3OBJ_CON_hostage_his_heir_certainly_get_great_achievement

Send him back, but keep the heir as a hostage, then you will certainly gain a great success.

c. 「得華登矣!」(zuǒzhuàn, zhāo 21.6.5) (LAC)

Dé_Huá_Dēng_y̌̀

Get__Hua_Deng__SFP

I got Hua Deng!

d. 育得其民, (guóyǔ, zhōuyǔ zhōng) (LAC)

Jìn_dé_qí_mín

Jin__get_POSS_people

... if Jin wins his people, ...

In the examples in (7) the dé-VP contains a $y u^{\prime}-\mathrm{PP}$; in (7a-c), the VP is ditransitive, the PP refers to a source. The goal subject is [+HUMAN]. In (7d), dé is intransitive with a theme subject; the PP refers to a goal or an affectee; the subject is [-HUMAN/+ABSTRACT]. 
(7)a. 「若得道於虞, 猶外府也。」(zuǒzhuàn, $x \bar{x}$ 2) (LAC)

Ruò_dé_dào_yú_Yú_yóu_wài_fŭ_yě

If_get_way_PREP_Yu_still_outside_treasury_SFP

If you get the way of passage from $Y$ u, it will still be [like in] a foreign treasury.

b. 「夷吾無禮, 余得請於帝矣, (zuǒzhuàn, xī 10) (LAC)

Yíwú_wú_lǐ_yú_dé_qŭng_yú_dì_yǔ

Yiwu_not.have_propriety_I_get_question_PREP_god_SFP

Yiwu does not have any propriety, I got [permission for] a request from the god.

c. 「吾不得志於漢東也, 我則使然。(zuǒzhuàn, huán 6) (LAC)

Wú_bù_dé_zhì_yú_Hàndōng_yě_wǒ_zé_shǐ_rán 1P_NEG__et_intention_PREP__Handong_SFP_I_then_make_SUF

If I do not get my will at/from Handong, this will be my own doing.

d. 故是非不得於身。(zhuāngž̌ 5.5.5) (LAC)

gù_shì_fềi_bù_dé_yú_shēn

therefore_right__wrong__

Therefore right and wrong are not found on him.

The examples in (8) show different kinds of negators modifying dé: in the first clause of (8a), it is the neutral negative marker bù, the internal argument, again the abstract noun zhì 志 (see also ex. (8c)), is present; in the second clause, the internal argument is not present overtly; dé is intransitive. In (8b), the negative marker fú, identified as default marker of transitive verbs in Djamouri (1991), precedes dé, the pronominal internal argument does not appear overtly, but according to the negative marker, dé is analyzed as transitive. In (8c), the aspectual negative marker wèi 未 negates dé; this negative marker is located in the Outer Aspect Phrase, typically negating telic verbs. In all examples, the subject is [+HUMAN], in (8a) and (8b) it is a goal subject, and in (8c), it is a theme subject. A [+HUMAN] subject seems to be the default case when dé appears as a lexical verb. The structures do not differ from non-negated structures. The analysis as a telic achievement verb is supported by its co-occurrence with the aspectual negative marker wèi in $(8 \mathrm{c})$.

(8)a. 成而不得志, 公子誉求令尹而不得, 故二子作亂。(zuǒzhuàn, wén 14) (LAC)

Chéng_ér_bù_dé_zhì_gōngzǐ_Xiè_qiú_língyǐn_ér_bù_dé_

gù_èr_zž_zuò__luàn

Accomplish_CON_NEG_get_intention_prince_Xie_search_Lingyin_CON_ _NEG_get_therefore_two_prince_make_chaos

This being achieved, he did not get his will. Prince Xie requested the position of

Lingyin, but it was not received (he did not receive it), therefore the two princes made chaos.

b. 弗得, 鞭之, 見血。(zuǒzhuàn, zhuāng 8) (LAC)

Fú_dé_biān_zhī_xiàn_xuè

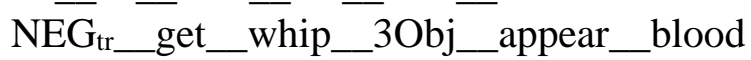

When he didn't get it, he whipped him until blood appeared.

c. 趙旃求卿未得, 且怒於失楚之致師者, (zuǒzhuàn, xuān 12) (LAC)

Zhào_Zhān_qiú_qīng_wèi_dé_

Zhao_Zhan__search__minister_NEG $\bar{N}_{\text {Asp__get }}$

qiě_nù_yú_shī_Chǔ_zhī_zhì_shī_zhě

furthermore_angry_PREP_loose_Chu_GEN_bring.about_army__REL 
Zhao Zhan requested the position of minister, but it was not obtained yet (= he had not succeeded yet). Furthermore, he was angry about having lost those who challenged the army of Chu.

Similar to the situation in the Early Archaic text Shijing, dé appears as an intransitive verb with a theme subject (VP1) and a transitive (and ditransitive) verb with a goal subject (VP2). The subject is predominantly [+HUMAN]. The intransitive construction in VP1 shows a wider range of subjects in LAC, allowing an occasional [+ABSTRACT] subject, than in Early Archaic Chinese.

(9) a. VP1: NP1 $1_{\text {theme }}$ [+HUMAN] $\mathrm{V} \rightarrow$ intransitive, one example with [-HUMAN] subject.

b. V1a: NP1 theme [+HUMAN]/[+ABSTRACT] V yú 于-PP $\rightarrow$ intransitive with locative PP/affectee (benefactive)

c. VP2: NP1 $1_{\text {goal }}\left[+\right.$ HUMAN] V NP2 ${ }_{\text {theme }}[+$ HUMAN] $/[+$ ABSTRACT $] \rightarrow$ transitive

d. VP2a:NP1 goal [+HUMAN] V NP2 $2_{\text {theme }} y u ́$ 于-PP $\rightarrow$ source

e. VP2b:NP1 $1_{\text {goal }}[+\mathrm{HUMAN}] \mathrm{V} \mathrm{NP} 2_{\text {theme }} y u$ 于-PP $\rightarrow$ benefactive, this seems to be confined to dé zuì

As an achievement verb, dé focusses on a result. Rappaport Hovav and Levin (1998: 104) propose the event structure template in (10a) for 'result verbs'. Two sub-events are involved in this representation, an activity in (10b), and a result state associated with achievements as in (10c).

(10) a. $[[x$ ACT $]$ CAUSE [BECOME $[y<$ STATE $>]]]$

b. $[x \mathrm{ACT}]$

c. $[$ BECOME $[\mathrm{y}<\mathrm{STATE}>]]$

The analysis of the argument structure of dé has shown that the [+HUMAN] subject/external argument in LAC is evidently rather a goal than an agentive subject. The goal subject may be involved in causing the GET event to happen, but it functions neither as direct agent nor as direct cause. Accordingly, the ACT feature is not expressed in the event structure of the lexical verb $d e ́$ even in the transitive structure. Two different possibilities arise with regard to the analysis of the transitive variant of dé: 1) a light verb INVOLVE instead of ACT could be proposed in the lexical semantics of dé, in order to link the external argument to VP. This is inspired by a proposal in Feng (2014) with regard to the light verbs in $v \mathrm{P}$ in Archaic Chinese and represented by (12d-f); 2) The external argument is severed from the verb as proposed in Kratzer (1996); according to this analysis, the examples (12d-f) can be removed from the representation of the lexical semantics of dé. We propose the following basic event structure of dé:

(11) $[\operatorname{BECOME~}[\mathrm{y}<\operatorname{STATE}=\operatorname{GET} / \operatorname{OBTAIN}(E D)>]]$

Including the possible adjuncts, the lexical verb dé can combine with in the event structure template, the following variants are attested in LAC:

(12) a. V1: [BECOME $\left[y_{\text {human/abstract }}<\right.$ GET $\left.>\right]$; clear restrictions on the theme subject, in comparison to the theme in object position

b. V1a: [BECOME [ $y_{\text {human/abstract }}<\mathrm{GET}>$ at $\left.\left.\left[\mathrm{P}_{\text {loc }} z\right]\right]\right]$

c. V1b: [BECOME $\left[y_{\text {human/abstract }}<\mathrm{GET} / \mathrm{OBTAIN}>\right.$ for $\left.\left[\mathrm{P}_{\text {bene/goal }} z\right]\right]$ ] (?)

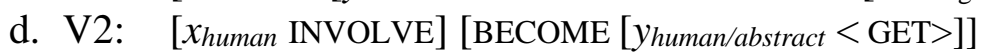

e. V2a: [x $x_{\text {human }}$ INVOLVE] [BECOME $\left[y_{\text {human/abstract }}<\mathrm{GET} / \mathrm{OBTAIN}>\right.$ from $\left.\left.\left[\mathrm{P}_{\text {source }} z\right]\right]\right]$ 


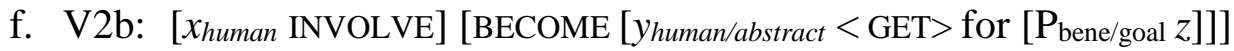

\subsection{Discussion of the argument structure of the lexical verb dé}

Due to its semantics and its argument structure, dé seems to belong to the verbs involving argument alternations within $v \mathrm{P}$. According to the classification provided in Levin (1993) for English verb classes and their alternations, two different classifications seem to be possible for $d e ́:$ 1) GET verbs, and 2) OBTAIN verbs. The latter include the English verbs 'accept, acquire, obtain, receive, regain, seize, select, ...' Most GET verbs allow a from phrase, and a for benefactive phrase, and they show a benefactive alternation (Levin 1993: 141f); they do not allow dative and locative alternations. ${ }^{8}$ Most OBTAIN verbs allow a from phrase, and a benefactive for phrase, but they do not show the Benefactive Alternation. They also do not allow dative and locative alternations. Example (13) shows the grammaticality of a benefactive alternation in English with the get verb 'buy', and the ungrammaticality of the benefactive alternation with the verb 'obtain' (from Levin 1993: 142).

(13) a. Carmen bought a dress for Mary.

b. Carmen bought Mary a dress.

c. Carmen obtained a spare part for Mary.

d. *Carmen obtained Mary a spare part.

The verb dé allows PPs with the preposition $y u$ 于/於, the most general preposition expressing relation in Archaic Chinese. One of its basic functions is to introduce a locative phrase, but it also introduces an indirect object, the agent of a passive construction, and the $Y$ element in a comparative structure. In the complement of dé, two basic functions are attested: a) in the transitive and telic construction, $y u$ introduces a source; and b) in the intransitive/unaccusative, resultant state construction, $y u$ introduces a locative complement. The benefactive (or rather malefactive) construction is almost exclusively confined to the combination dé zuì 'acquire guilt against' (in ex. (4d)). In this construction, the PP is possibly also locative 'in front of', or simply relational 'in relation to'. In contrast to the English GET and OBTAIN verbs, no alternations within VP seem to be attested; a few late examples from Early Middle Chinese show an alternation between a double object construction and a prepositional construction ' $\mathrm{V}$ NP2 from NP3' and 'V NP2 NP3', i.e. the source is syntactically realized as a second internal argument as in example (14b) from the Shiji. ${ }^{9}$ No change of position of the source argument is involved. Thus, this construction differs from typical ditransitive verbs in LAC, which allow the dative alternation: NP1 V DO to IO $\leftrightarrow$ NP1 V IO DO. This construction only seems to be attested with the internal argument xing 幸. This shows that $d e$ is clearly distinct syntactically from the corresponding English verbs and also from typical ditransitive verbs of the give or take type in LAC.

(14) a. 聞臣之得幸於王也， (zhànguó cè 25.25.3) (LAC-EMC)

Wén_chén_zhī_dé_xìng_yú_wáng_yě

Hear_subject_GEN_get_favor_PREP_king_SFP

if one hears that [someone like] me is gaining favor from the king, ...

b. 得幸武帝, 生子一人, (shiji 49: 1985) (EMC)

Dé_xìng_Wǔdì_shēng_zǐ_y $\overline{1} \_r e ́ n$

\footnotetext{
${ }^{8}$ GET and RECEIVE verbs are briefly discussed in Dowty (1991: 581) as historically particularly interesting. The examples in the Oxford English Dictionary for both verbs imply that 'active' senses were as common as 'passive' (non-volitional) senses.

${ }^{9}$ In the Early Middle Chinese period, the Chinese language underwent a number of structural changes which also involved the employment of PPs with yú in ditransitive and other constructions.
} 
Get_favor_Wu_emperor_give.birth_son_one_man

she gained favor from/with emperor Wu and bore one son.

On the other hand, dé apparently shows some features characteristic for middle constructions in transitivity alternations. According to Levin (Levin 1993: 26), middle constructions are characterized by "a lack of time reference and by an understood but unexpressed agent. More often than not, the middle construction includes an adverbial or a modal element." (e.g. Alexiadou 2014). This distinguishes them from the causative/inchoative alternation. ${ }^{10}$ An example would be:

(15) a. The butcher cuts the meat.

b. The meat cuts easily.

The same kind of modification is also attested with dé in a similar meaning, modified by the adverb yì 易 'easily'. The Academia Sinica shànggŭ corpus (http://hanji.sinica.edu.tw/ accessed September 25, 2018) shows 21 hits of yì dé 易得 'easily get' in LAC and EMC texts, of those, only one instance is transitive. All other instances are intransitive (unaccusative) with a theme subject. Additionally, they are all generic; i.e. they display at least some of the features typical for middle constructions. The basis for the generic reading in the examples represented in (16) is the intransitive/unaccusative variant of dé and the combination with yì 'easily'. Two analyses are possible for an intransitive $v \mathrm{P}$ with a theme subject in LAC, a passive analysis and an unaccusative analysis. ${ }^{11}$ Although dé in LAC predominantly functions as a transitive verb, the intransitive constructions with a theme subject are evidently unaccusative and not passive. This analysis is supported by the fact that in none of the examples discussed above with a $y u^{\prime}-$ PP, the PP introduces an agent, although the introduction of the agent is one of the regular functions of the $y u$-PP. According to Alexiadou and Schäfer (2013), the introduction of an agent by a PP (by-phrase in English) is licensed in passive constructions, but not in unaccusative constructions. Thus the examples with the PP yú clearly show that $\mathrm{NP}_{\text {theme }}+d e$ has to be analyzed as unaccusative and not as passive. ${ }^{12}$ Despite the semantic similarities with the examples in (15), the middle analysis does not seem to account for dé in the examples (16), though. This is due to the transitivity constraint on verbs that can enter the middle construction discussed in Xiong (2017) referring to Marelj (2004) and Fagan (2009: 97). Marelj (Marelj (2004: 10f, cf. Xiong 2017: 110f) proposes that only verbs with Cause, Agent or Instrument roles can enter the middle construction. Receive is not acceptable in the middle construction, because it does not contain the CAUSE feature (see Xiong 2017: 112). Xiong (2017: 211f) analyses constructions with a resultative verb and with rongyi/nan 'easy/difficult' in Modern Chinese as instantiations of the tough construction and not as middles. Although dé is not a complex resultative verbal predicate like the predicates discussed in Xiong, the same analysis can account for both dé and for yòng 用 'use, employ' in the examples in (16), modified by yì

\footnotetext{
${ }^{10}$ An argument against the structure with dé as a middle construction is the fact that dé is an achievement verb, which makes an analysis as lexical middle unlikely (following Fagan (2009, cf. Xiong 2017: 29) on German, English and French middles). On the other hand, Lekakou (2009: 99, cf. Xiong 2017: 51) claims that, "an otherwise eventive verb becomes a derived state, and, more precisely, receives a generic interpretation." Middle verbs and unaccusatives have in common that they do not assign case (see Xiong's (2017: 34 discussion of Hale and Keyser's (2002) analysis of middles).

${ }^{11}$ Although a number of verbs in Archaic Chinese could be marked morphologically for resultativity/telicity (see e.g. Jin 金理新 2006, Schuessler 2007, Meisterernst 2016, Aldridge and Meisterernst 2019), there was apparently never a morphological distinction between the passive and the unaccusative.

${ }^{12}$ A second test Alexiadou and Schäfer (2013) propose is Control: a passive agent can control a PRO of a rationale clause + , unaccusative -.
} 
'easy' and nán 難 'difficult' respectively. ${ }^{13}$ However, the unaccusative function and the semantic similarity with middle constructions may have contributed to the development of dé into a postverbal resultative marker, and into the middle construction with DE.

(16) a. 「悲夫！士何其易得而難用也！」(zhànguó cè 11.9.1) (LAC-EMC)

Bēi_fú_shì_hé_qí_yì_dé_ér_nán__yòng_yě

Sad_SFP_officer_why_MOD_easy_get_CON_difficult_employ_SFP

How sad! Why are officers to be found easily, but to be employed with difficulty?

b. 惟余一人, 有善易得而見也, 有不善易得而誅也。」(lüshì chūnqiū 20.2.3)

(LAC)

Wéi_yú_yī_rén_yǒu_shàn_yì_dé_ér_jiàn_yě

COP_I_one_man_have_good_easy_get_CON_visible_SFP

Yǒu_bù_shàng_yì_dé_ér_zhū__yě

Have_NEG_good_easy__get_CON_punish__SFP

For me alone, if they are good, they are found easily and made visible, if they are bad, they are found easily and punished.

\subsection{The aspectual and modal structure of dé}

Dé is a typical achievement verb in Archaic Chinese. Both, the transitive and the intransitive variant clearly refer to a final point of the situation, the BECOME feature. The analysis of the argument structure of dé in the event structure template in (11) demonstrates that dé functions as an achievement verb even in the transitive variant. No ACT or CAUSE sub-event is involved in the lexical structure of dé. The external argument may be involved in the BECOME <STATE> event, but is not linked to an ACT event by an acting or causing relation.

In the temporal structure provided for terminative, i.e. telic situations in Abraham and Leiss (2008: XIV), a predicate with dé either refers to $t_{m}$, the change of state point from a process $\left(\mathrm{E}_{1}\right)$ to a resultant state $\left[\mathrm{E}_{2}\right]$, or to the resultant state $\mathrm{E}_{2}$. In (17), the INVOLVE event includes the goal subject Jin and the process $\mathrm{E}_{1}$ leading to the resultant state, starting with $\mathrm{t}_{\mathrm{m}}$ which indicates that the theme 'his people' are won. In (18), only the $\mathrm{t}_{\mathrm{m}}$ and the resultant state part $\mathrm{E}_{2}$ are present in the structure.

(17) a. 晉得其民, (guóyǔ, zhōuyǔ zhōng) (LAC)

Jìn_dé_qí_mín

Jin__get_POSS_people

... Jin wins his people ...

b. $|>\gg>>>>>>>| \ldots \ldots \ldots \ldots . . . \mid$

$\begin{array}{lllll}\mathrm{t}_{1} & \mathrm{E}_{1} & \mathrm{t}_{\mathrm{m}} & \mathrm{E}_{2} & \mathrm{t}_{\mathrm{n}}\end{array}$

$[x$ INVOLVE $] \quad$ [BECOME $\left[{ }_{Y}<\right.$ STATE $\left.\left.>\right]\right]$

[Jin INVOLVE] [BECOME [people $\langle$ WIN $>]]$

(18) a. 信, 禮之亡, 欲免, 得乎? 」(zuǒzhuàn, chéng 15) (LAC)

Xìn_lǐ_zhī_wáng_yù_miăn_dé__hū

Trustworthiness_propriety_GEN__emise_wish_avoid_succeed_SFP/Q

\footnotetext{
${ }^{13}$ See Xiong (2017: 117) citing Bassac and Bouillon (2002)) 'the verb use is treated as an activity verb ... and is therefore excluded from the middle construction. Modern Chinese (shi)yong 'use' is acceptable in the qilai middle construction (Xiong 2017: 120), though.
}

(i) Zhe__xie_chufang_yongju_yong__ilia_hen_fangbian

The__PL_kitchen__utensil_use_QILAI_very_convenient

It is convenient to use these kitchen utensils. (cf. Xiong 2017: 119) 
'When trustworthiness and propriety perish and one wishes to avoid it, will it be gained (= will one be successful?)'

b. $|\gg \gg \gg \gg \gg \gg>| \ldots \ldots \ldots \ldots . . . . \mid$

$\begin{array}{lllll}\mathrm{t}_{1} & \mathrm{E}_{1} & \mathrm{t}_{\mathrm{m}} & \mathrm{E}_{2} & \mathrm{t}_{\mathrm{n}}\end{array}$

[BECOME $\left[{ }_{Y}<\right.$ STATE $\left.\left.>\right]\right]$

[BECOME $\left[\right.$ protheme $_{\text {the }}<$ GAINED>]]

Achievement verbs can be modified by the perfective adverbs 既 $j i ̀$ 'already', 已 $y \check{\imath}$ ' 'already, and by the aspectual negative marker 未 wèi 'not yet'. These adverbs have been analyzed as attached to the Outer Aspect Phrase in (Meisterernst 2016); as perfective adverbs, they naturally combine with [+TELIC] verbs; with atelic verbs they signal completion. Telicity is hosted in the Inner Aspect Phrase within $v \mathrm{P} .{ }^{14}$ The perfective adverbs frequently combine with the sentence final particle 矣 $y \check{\imath}$, which has been compared to the sentence final particle 了 le in Modern Mandarin (e.g. Pulleyblank 1995). Y̌ appears in the lowest layer of SFPs in Chinese, possibly as the head of the Outer Aspect Phrase; it marks finiteness. In contrast to another typical telic verb, the verb 治 chí/zhì 'govern/governed >> in good order', the verb dé occurs relatively frequently in combination with one of the aspectual adverbs $j i$ and $y \check{r} .{ }^{15}$ The reason for this may be that dé belongs to the verbs of receiving which are excluded from the morphological changes typically associated with resultativity; thus, the resultative/perfective reading is more liable to be marked by an adverbial. The verb chí/zhi 'govern/governed' on the other hand shows one of the possible morphological alternations connected to meanings of telicity and resultativity. These are a) an alternative reading in the qùshēng resulting from a former $*_{-s}$ suffix (first proposed in Haudricourt 1954, also Downer 1959; Unger 1983; Sagart 1999; Jin 金理新 2006, Schuessler (2007 etc.).), or b) an alternation between voiced and voiceless initials (Karlgren 1933; Mei 梅祖麟 1988; Baxter and Sagart 2014, etc.). In LAC, verbs which show morphological alternations tend to occur less frequently with the perfective adverbs $j i ̀$ and $y \grave{\imath}$ than verbs not showing these alternations (including verbs which only appear in the qùshèng) (Meisterernst 2015b, Aldridge and Meisterernst 2018 and references therein). The two different readings have been recorded for zhì already in the Jingdiăn shìwén ( $6^{\text {th }} \mathrm{c}$. CE) by Lu 陸德明 (550-630), based on earlier phonological commentaries. They have been reconstructed as $\left({ }^{*} r-\right.$ $d e, * r-d e-s)$ in Jin 金理新 (2006). Different functions have been attributed to the reconstructed $*_{-s}$, connected to perfectivity, passive readings, and most recently to resultativity and telicity (Meisterernst 2015b, 2016, 2019a, Aldridge and Meisterernst 2018, and reference therein). The examples in (19) show dé modified by jì (19a), by y̌̌ (19b), and by wèi and jì (19c).

(19) a. 市人將畔, 臣討之, 既得之矣。(guóyǔ, lǔyǔxià) (LAC)

Biàn_rén_jiāng pàn_chén_tǎo_zhī jì_dé_zhī_yì

Bian_people_rebel_subject_punish_oBJ_PERF_get_OBJ_SFP

Someone in Bian wanted to rebel, and I punished him, and I have already gotten it.

b. 今已得地而求不止者 (zhànguó cè 10.1.9) (LAC-EMC)

jīn_y̌̃_dé_dì_ér_qiú_bù_zhǐ_zhě

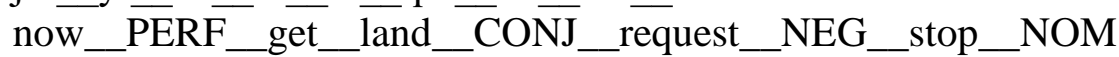

Now she has already got the land, but her demands do not stop ...

\footnotetext{
${ }^{14}$ For a discussion see Meisterernst (2016) and the references therein.

15 A search of the sequence $j \grave{l} / y \grave{l} d e ́$ and jì $y \check{\imath}$ zhì in the Shanggu corpus of Academia Sinica (http://hanji.sinica.edu.tw/ accessed September 25, 2018) displays the following hits: jì dé: 70, jì zhì: 3; y̌́ dé: 65, $y \check{\imath} z h \grave{i}$ : 17. The increase of marking by $y \check{\imath}$ with $z h \grave{\imath}$ is expected, because $y \check{\imath}$ is later than $j \grave{\imath}$ and appears at a time when the number of aspectual adverbs generally increases; this is supposedly caused by the loss of transparency of the former morphology (see Meisterernst 2017, 2019a).
} 


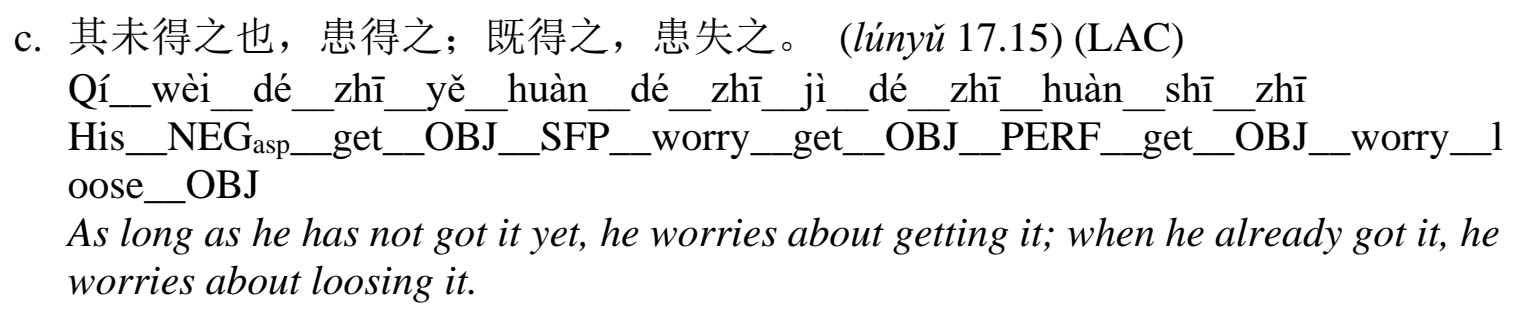

A characteristic feature dé has in common with other auxiliary verbs is the employment of the first person pronoun 吾 wú in subject position. Wú is more frequent than the other common $1 \mathrm{P}$ pronoun 我 wǒ (12 $\Leftrightarrow 7$ in Zuǒzhuàn) in combination with dé as both lexical and auxiliary verb. This has already been stated in Gabelentz in 1881 (1960: $\S 1092 \mathrm{f}$ ). Whereas wó can stand for a nominative subject and for any kind of object, Gabelentz analyzes wú as mostly, but not exclusively genitive. He states that when wú appears as the subject in combination with an adverb or an auxiliary word, the subject has genitive case. All the can-wish verbs of LAC, i.e. all the early auxiliary verbs appear more frequently with wú than with wŏ. This is also true for volitional verbs and verbs of participant internal ability. This may be accounted for by the irrealis mood of modal verbs, which imposes different constraints on the subject (Aldridge p.c.). ${ }^{16}$ In most of the instances with wó, the pronoun seems to be in contrastive focus or has plural reference (Aldridge, p.c.); wǒ is historically the default pronoun to express the plural of the $1^{\text {st }}$ person. In (20a), the first person pronoun wú appears in a non-contrastive context, referring to a goal and not to an agent; in (20b), wǒ appears in contrast to the term of address $z \check{l}$ 子 in the first clause.

(20) a. 「吾得罪於君, 悔而無及也。(zuǒzhuàn, xiāng 20)」LAC) wú_dé_zuì_yú_jūn_huǐ_ér_wú_jí_yě I__get_guilt_PREP_ruler_regret_CON_not.have_arrive_SFP I incurred guilt towards my ruler, regret does not lead anywhere.

b. 子得其國寶, 我亦得地, (zuǒzhuàn, chéng 2) (LAC) zǐ_dé_qí_guó_băo_wǒ_yì_dé_dǐ You_receive_its_country_treasure_I_also_receive_land You will get the treasures of the country, and we will also get the land ...

\subsection{Concluding remarks on the lexical verb dé}

The discussion above demonstrates that the lexical verb dé is unambiguously an achievement verb; it is first slightly more frequently attested in intransitive, unaccusative constructions with a theme subject ( 8 instances vs. 6 unambiguous transitive instances in the Shijing). According to proposals made on the morphosyntax of Chinese e.g. in Jin 金理新 (2006), it belongs to the class of verbs of receiving (得到 dédào), which are characterized by the fact that they never appear in the qùsheng alternation. This implies that they do not belong to the class of verbs, for

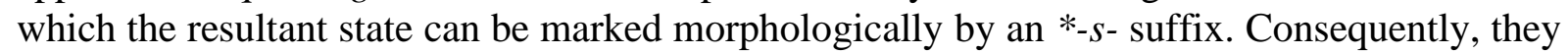
are more frequently modified by perfective adverbs in LAC, which mark them as telic, referring to a resultant state. During the LAC period, the employment of dé increases, and it is predominantly employed as a transitive verb with a goal subject. Also in its transitive use, no ACT/CAUSE feature seems to be involved in the event template of dé; this argues for the existence of genuine transitive achievement verbs in LAC (see Meisterernst 2015a, 2016). The lexical semantics and the argument structure of dé have some features in common with for instance the

\footnotetext{
${ }^{16}$ According to Dowty (1991: 578), goals are obliques in many cases; this may also account for the employment of wú, which supposedly has a non-nominative case (Aldridge 2015). As an achievement verb, and as an implicative verb, dé frequently expresses realis mood rather than irrealis mood.
} 
English GET and OBTAIN verbs. Similar to the English verbs of this category, the expression of a source, corresponding to a from phrase and a restricted set of benefactive for phrases are licensed in the argument structure of dé. But in contrast to the English verbs, no alternations, such as dative or locative alternations within VP seem to be attested. Constructions with the adverb yì 易, which have a generic reading and resemble middle alternations, also permitted for some of the English GET/OBTAIN verbs, rather have to be analyzed as tough constructions than as middle constructions.

\section{The diachronic development of dé}

\subsection{An introduction to the modal marker dé and its different functions}

The grammaticalization of GET verbs into auxiliaries is well attested in the literature (Heine and Kuteva 2019); Chinese is one of the exemplary cases. Heine and Kuteva (2019) show that GET verbs can grammaticalize into past tense markers (e.g. in Khmer), into markers of possibility (Chinese, Burmese, English, Lahu, Vietnamese), or permission (Chinese, English). The precondition for the grammaticalization of a lexical verb into a modal auxiliary verb is the licensing of a VP complement in the argument structure of the pre-modal verb. Complements which are ambiguous between an NP and a VP analysis open the path for a reanalysis of dé as an auxiliary verb. One of the triggers for the extension of the system of modal auxiliaries in EMC was possibly the loss of transparency of the former derivational aspectual morphology of the verb, briefly discussed in section 2.3 , as one of a number of structural changes in Chinese at that time (Aldridge, e.g. 2013, Feng 2014, Aldridge and Meisterernst 2018, Meisterernst 2019a, 2020a). Due to this change, morphological distinctions between nouns and verbs ceased to be productive. The examples in (21) demonstrate how ambiguities between a VP and an NP analysis arise. 成 chéng in (21a), 'complete, accomplish', 'achievement' is a typical transitive verb, but in the example it appears without an internal argument. An unaccusative or passive analysis of chéng in the complement of dé is not possible, since the subject of chéng cannot be analyzed as its internal argument. This argues for the NP analysis of chéng 'achievement'. 進 jìn 'advance, move forth; enter, present' in (21b) on the other hand can appear as an intransitive (unergative) verb, and 死 $s \check{l}$ ' die' in (21c) is a typical unaccusative verb; the internal argument appears in subject position. Since jìn can appear as an intransitive unergative verb and $s \grave{\iota}$ is intransitive in its basic argument structure, their analyses as VPs are not problematic; no violation of their argument structure is involved as it would be in the VP analysis of chéng in (21a). Consequently, the analysis of dé in (21b) and (21c) as a modal auxiliary verb is more likely than in (21a). (21d) shows the analysis of the process of grammaticalization of (21b) from lexical verb with NP complement to modal verb with VP complement. The examples in (22) all show transitive complements with overt internal arguments following the complement verb. In these cases, the complements of dé are not ambiguous anymore between an NP and a VP analysis.

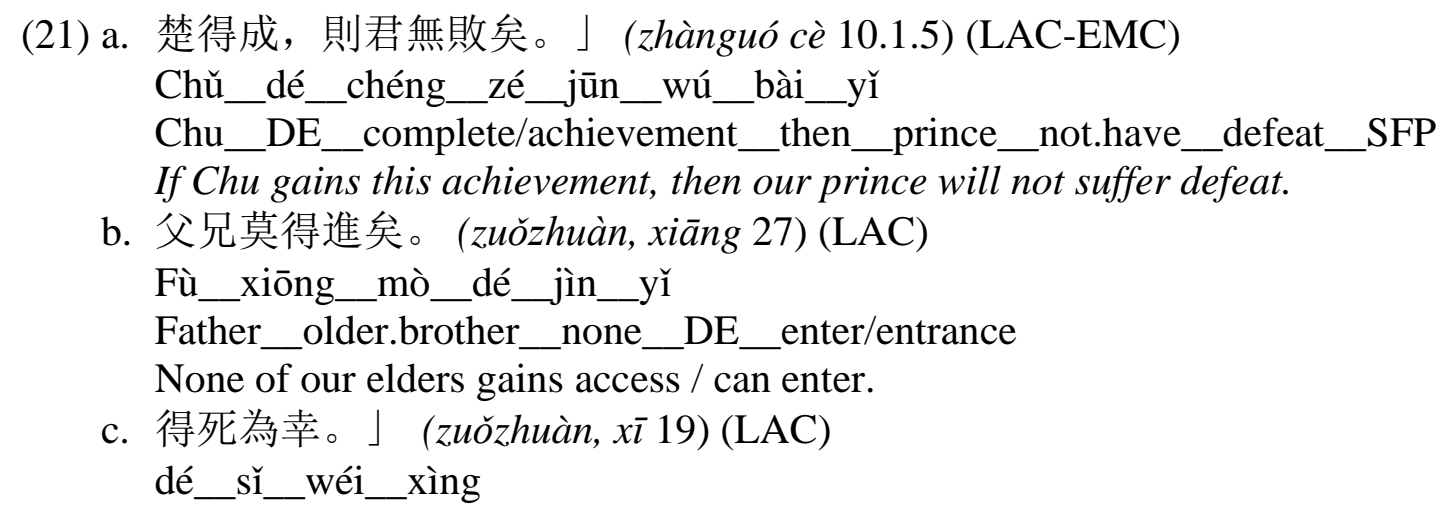


DE_die/death_be_fortunate

To gain [a natural] death/ to be able to die, will become fortunate.

d. [vp DE 'GET/GAIN [NP jin 'access]] $\rightarrow$ [vP [vP/ModP DE 'can' [vP jin 'access']

(22) a. 且子懼不孝, 無懼弗得立。(zuǒzhuàn, mǐn 2) (LAC)

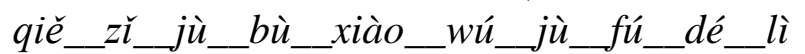

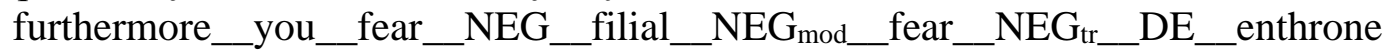

Furthermore fear, not to be filial, don't fear that they will not enthrone you.

b. 僑焉得恥之? (zuǒzhuàn, zhāo 16) (LAC)

qiáo_yān_dé_cȟ̀_zhī

Qiao__how_DE_ashamed_3Obj

How could I, Qiao, be ashamed of it?

c. 葟君知不得事君矣 (zuǒzhuàn, zhāo 13) (LAC)

guă_jūn_zhī__bù_dé_shì_jūn_yì

Lonely_prince_know_NEG_DE_serve_ruler_SFP

My prince knows that he cannot serve you, my prince.

Dé as a modal auxiliary verb is less frequent than the lexical verb dé in Zuǒzhuàn; as an auxiliary verb, it is infrequent in Guóyŭ, and it is also not very frequent in Lúnyǔ, Mòž́, Mèngzž, Xúnž̆, Zhuāngž̌. Liu 刘利 (2000: 156) presents the following figures: 18 instances of dé as auxiliary verb in Lúnyǔ (33.5\% of its occurrence), 21 instances in Guóyǔ (14.5\%), 74 instances in Zuǒzhuàn (45.6\%), 162 in Zhànguó cè (40.6\%). However, a closer look at the unambiguous instances of $d e ́$ as a modal auxiliary in the Lúnyǔ results in a lower number of instances. Unambiguous instances exclude those with a complement which allows both the NP and the VP analysis and instances with the connector ér 而 appearing between dé and VP. ${ }^{17}$ The entirely unambiguous instances in the Lúnyǔ amount to only seven out of 48 (14.6\%). Liu 刘利 (2000) in his comprehensive study of modal auxiliary verbs in LAC particularly focuses on the different modal readings of dé in rhetorical questions and in combination with negation; these are the environments, in which deontic modal readings are supposed to appear first (see also $\mathrm{Li}$ 李明 2001, Meisterernst 2020a, 2020b). This is not the main issue of this study. Instead, the focus lies on the aspectual and argument structure of dé in order to show the triggers for the multiple functions of dé, including its function as a post verbal marker.

The dependence of the modal reading of dé on the lexical aspect and the temporal structure of the embedded verb has been generally acknowledged. According to Dobson (1959: 53, note 19), dé basically has an aspectual meaning. Dobson seems to assume that modal predicates with event verbs, e.g. verbs with resultative aspect, receive a deontic reading, while those with atelic verbs receive a possibility reading. ${ }^{18}$ A close relation between the reading of $d e$ and the aspect

${ }^{17}$ Liu 刘利 (2000: 58f) analyses dé in the construction dé 而 ér VP as auxiliary verb. One of his arguments for this is that dé and the verb following ér share the same object. However, object sharing of two VPs is not a characteristic feature of an auxiliary verb and its complement. Additionally, the construction V1 ér V2 is also attested with other verbs. The example below is an instantiation of a subordinated VP preceding ér and sharing the same object with the following verb. If the object is the pronoun $z h \bar{l}$, it is only expressed once following the second V (Unger 1988: 65).

(i)

棄而違之。(lúnyǔ 5.19.3) (LAC)

Qì_ér__wéi_zhī__

Abandon_ER_turn.against_OBJ

Abandoning him he turned against him.

For a discussion of this structure (including the structure dé ér VP) and for more examples see also Mei 梅廣 2015: 200f).

${ }^{18}$ Dobson (1959: 53, note19: “得 thus operates in two forms in the verbal syntagma: 得與 “ought to give”, 得受 “should receive” but 得見 “succeed in seeing”." 
of the verb in the complement of dé has also been assumed in $\mathrm{Li}$ 李明 (2001). He proposes that if the verb selected by dé has a perfective/resultative reading, the meaning of dé is 'reach'; if the verb has an imperfective/incomplete reading, dé expresses possibility. The reading can be marked by an aspectual (perfective) adverb, such as ji 既 'already', preceding dé ( $\mathrm{Li}$ 李明 2001: 16f). This adverb does not appear in the complement of dé. The adverb is adjoined to the Outer aspect phrase (Meisterernst 2016) and is accordingly located outside $v \mathrm{P}$. It denotes that the entire predicate is located in the past and that the event expressed by the matrix verb is complete (see also the examples in (19), discussed above). In the examples in (23) the entire modal predicate is marked for aspect; in (23a), for perfective aspect by the adverb jì. In (23b), it is marked by a combination of the aspectual negative marker wèi and the adverb 嘗 cháng: wèi cháng 'never in the past', referring to a past non-event. In both examples, dé has an implicative reading; this is the default reading of dé in past test contexts. The different readings of the modal auxiliary dé are discussed in the following sections.

(23) a. 『舜往于田，則吾既得聞命矣； (mèngž̌ 5.1.1) (LAC)

Shùn_wăng_yú_tián_zé_wú_jì_dé_wén__mìng_yì

Shun_wander_PREP_field_then_I_ JI_DE_hear_mandate_SFP

That Shun wandered around in the fields, I already managed to understand its meaning, ...

b. 未嘗得聞社稷之長計。(zhànguó cè 19) (LAC-EMC)

Wèi_cháng_dé_wén__shèjí_zhī_cháng_jì

$\mathrm{NEG}_{\text {asp__PAST_DE__hear_state_long_plan }}$

I never before managed to/could hear about long-range plans for the state.

Semantically, the modal auxiliary dé in Pre-Tang Chinese is associated with different possibility meanings similar to the English modal 'can' and the semi-modal 'to be able to'. The English modal can involves meanings of 'ability, opportunity', but also 'capacity, skill', "and even 'right"' (Austin 1970: 320, note 17). Most of these meanings can also be associated with dé in Pre-Tang Chinese, similar to kě $(y \grave{\imath})$, the earliest modal auxiliary of possibility attested in Archaic Chinese. The modal auxiliary néng, also attested early in Chinese, predominantly expresses ability and is a participant-internal modal according to van der Auwera and Plungian's (1998) classification. By contrast, kě and dé are basically participant external modals, i.e. they express possibilities induced by external factors (for an analysis of $k e ́$ as predominantly a circumstantial root modal see Meisterernst 2008a). ${ }^{19}$ For postverbal de in Modern Mandarin three different readings have been proposed in Xie (2012: 393): a) an ability reading; b) an opportunity reading; and c) a disposition reading. As already mentioned these readings all "have to do with the potential to cause or undergo "change of state" that is attributable to properties of the subject and/or of the utterance contexts (Hackl 1998; Bhatt 1999)." Thus, they fit well the telicity features of both the modal dé and its default complement; the basic meaning of the lexical verb dé always includes the change of state of 'not having' to 'having received/gotten/obtained'.

As an event verb, dé is a typical change of state verb. It can be distinguished from the other possibility modals by its syntacto-sematic features as a transitive achievement verb with a goal subject and as an intransitive achievement verb with a theme subject. Additionally, its functions as a semi-modal implicative verb, similar to 'manage to' in English, are not modal in the strict sense; this is discussed below. The latter, and the feature of dé as an achievement verb expressing a result, may account for its particular diachronic development into the postverbal

\footnotetext{
${ }^{19}$ According e.g. to Huang et al. (2009), both néng and kěyı̌ are control modals in Modern Mandarin (2009: 110). A qualification of néng as a possible control modal in LAC is still pending, but kě(y̌̀) is most certainly a raising modal in LAC.
} 
element DE introducing manner and result. Cheng and Sybesma's discussion on potential DAK in Cantonese, the correspondence to DE in Modern Mandarin, accounts for the result reading of DAK by proposing that it is located in a resultative small clause. They discuss two different readings of DAK, a root (deontic) permission reading and a potential reading. They argue that $d a k$ is a verb (though defective) which is inserted in two different positions in order to derive the different readings: for the deontic reading, 'can' is inserted in the matrix clause, and for the potential reading it is inserted in the resultative small clause. They present the following examples for the different readings of DAK.
(24) a. keoi Zzaa-dak - - li-ga _ce
s/he can [i.c., is permitted to] drive this car.
b. keoi_lo-dak-hei_li-seung_syu
$3 \mathrm{~s}$ _take-DAK-up_this-box__book
s/he can [i.e., will manage to] lift this box of books.

More research on the topic is required, but Cheng and Sybesma's analysis points to the possibility that the functions of postverbal dé actually derive from the semi-modal lexical verb dé 'get, obtain', and not from the auxiliary verb dé, which emerged during the LAC period, although the semantics of postverbal dé and of the auxiliary verb dé show a considerable overlap. This will be briefly discussed in section 4 (see also Meisterernst 2019b).

Similar to the verb of possibility kě/kěyl̆, which regularly expresses deontic modality in polarity contexts, i.e. rhetorical questions and negation, dé also functions as a deontic modal marker. An opportunity reading, i.e. a circumstantial possibility reading, is common to all examples with the auxiliary verb dé whether in the present, future, or past tense. It is also the meaning underlying the derived deontic readings. As already mentioned, Dobson (1959: 53) relates the deontic reading of $d e$ to the aspectual features of the complement verb, i.e. to a complement verb showing resultative aspect. What Dobson refers to is rather the fact that dé by default has event complements, i.e. telic verbs, which are compatible with the perfective aspect. Perfective aspect is not marked by perfective adverbs, though; the default complement of the auxiliary verb dé does not have any temporal or aspectual marking. Additionally, a telic verb does not necessarily trigger a deontic reading of the modal predicate.

In the following sections, the possibility, i.e. circumstantial, and the deontic readings of dé in LAC and EMC are introduced briefly. According to Tsai's (2015) cartographic approach, circumstantial readings are located in the lexical layer, i.e. in $v \mathrm{P}$, deontic modals are loated in the TP layer. Following the terminology proposed in Xie's analysis of postverbal DE and Bhatt's (1999) studies on Ability modals, we propose that the basic meaning of dé is to express participant-external circumstantial or opportunity modality. Depending on the temporality of the predicate, dé either expresses possibility (see also $\mathrm{Li}$ 李明 2001) or has an implicative meaning. The two other meanings of dé proposed in Xie (2012), ability and disposition are extremely infrequent in the Late Archaic and Early Medieval literature.

\subsection{Ability and disposition readings of the auxiliary verb dé}

Ability and opportunity modalities differ by the fact that the first is stative, referring to "stable properties of an individual", i.e. ability modals behave like individual level predicates. By contrast, opportunity modals behave like stage level predicates, involving a change of state, a temporal element (Xie 2012: 391). Although ability is stative, referring to a special type of potential of the agent, it is also dynamic "when it comes to the agent's actualization of his internal ability in a world." (Xie 2012: 403) Xie (2012) claims that the ability reading requires an agentive subject. As the examples demonstrate, according to this constraint true ability readings are very infrequent with dé. This is not surprising considering the fact that the basis 
for the modal auxiliary verb, the lexical verb dé usually has a goal and not an agent subject. In (25a), dé appears parallel to the ability modal néng. The difference between néng 能 and dé is: 1) participant-internal ability with néng, 2) participant-external circumstantial possibility with dé. In the coordinated clauses in (25a) both subjects are agentive, thus an ability reading seems possible; the reading in (25a) is generic. In (25b), the subject of the complement verb 見 jiàn 'see' is an experiencer; thus, it is non-agentive. According to the circumstances of being a woman, a nun does not have the disposition allowing her to see the Buddha first. In the first clause of (25c), the subject, the robbers, have the ability or capacity to change; the sentence has a generic reading; de clearly adds the semantic reading of possibility to the proposition. The subject has to be analyzed as a theme and not as an agent in both clauses. The reading in (25d) is generic, too; the subject is [+HUMAN], but as the subject of a psych verb, it is rather an experiencer than an agent. In example (25e), the subject of $d e$ is contrasted to the subject in the first clause, Jìn and Chŭ, therefore the $1^{\text {st }}$ person pronoun wǒ appears; the complement verb is the existential verb 有 yŏ $u$ followed by 信 xìn 'belief'. Since the predicate is a psych predicate, the subject is non-agentive. The example in (25d), can also be generic under certain conditions. All examples imply that circumstances enable or prevent the obtainment of the predicated situation.

(25) a. 至人之所不得逮, 賢人之所不能及, (zhuāngž̌ 29.3.6) (LAC)

zhì_rén_zhī__suǒ_bù_dé_dài_

utmost_man_GEN_REL_NEG_DE_achieve_

xián_rén_zhī__suǒ_bù_néng_jí

virtuous_man_GEN_REL_NEG_able.to_arrive

This is what a perfect man cannot achieve, what a virtuous man cannot arrive at.

b. 我是女人。何由得先見佛。(taishō 51, n. 2085, p. 859c) (late EMC)

Wǒ_shì_nürén_hé_yóu_dé_xiān_jiàn_fó

I_COP_woman_how_from_DE_first_see_Buddha

I am a woman, how could I see the Buddha first?

c. 盜賊得變, 此不得變也。(xúnzǐ 5/10/4) (LAC)

Dào_zé_dé_biàn_cč_bù_dé_biàn_yě

Robber_thieve_DE_change_this_NEG_DE_change_SFP

Although robbers and thieves can change, these could not be changed.

d. 對曰:「非小人之所得知也。」 (zuǒzhuàn, chéng 9.9.1) (LAC)

Duì_yuē:_fēi_xiăo_rén_zhī_suǒ_dé_zhī_yě

Answer_say_is.not_small_man__SUB_SUO_DE__know_SFP

He answered, 'This is not something a small man can know.'

e. 晉、楚無信, 我焉得有信? 」(zuǒzhuàn, xuān 11) (LAC)

Jìn_Chú_wú_xìn_wǒ_yān_dé_yǒu_xìn

Jin_Chu_not.have_faith_I_how_DE_have_faith

Jin and Chu do not have faith, how can we manage/ be able to have faith.

Most of the examples presented in (25) are more liable to a disposition than to an ability reading. Both readings are not very frequent in LAC and EMC. In contrast to ability modality, which is characterised by the requirement of an agentive subject, the disposition modal does not have an agentive subject. ${ }^{20}$ Ability and disposition modals both seem to display the same temporal constraints, i.e. they are usually not compatible with past-denoting temporal phrases; in past denoting contexts, an implicative reading is involved. (Xie 2012: 402). The same

\footnotetext{
${ }^{20}$ See Xie (2012: 392, 402): "The disposition reading is different from the ability reading merely in regard to whether the subject is agentive or not."
} 
constraints, Xie proposes for postverbal DE in Modern Mandarin, also seem to account for the modal auxiliary verb dé in LAC and EMC. The examples demonstrate that the ability/disposition readings have a strong tendency to be generic, and they are excluded from past contexts. This is an argument in favour of the status of dé as a typical implicative verb, which shows different readings according to temporal constraints.

\subsection{Opportunity reading of the auxiliary verb dé}

As mentioned already, opportunity modals involve a change of state, a temporal element (Xie 2012: 391); they are stage level predicates. As a typical change of state verb, dé is particularly liable for readings of this kind. According to Xie's study, the expression of opportunity modality can include past-denoting temporal phrases. The opportunity modal reading of the auxiliary verb dé may be captured best by the English semi-modal 'able to', and dé actually seems to function in a manner very similar to 'able to' in English. According to Bhatt (1999: 184), ABLE is a non-stative implicative verb similar to 'manage to' (which involves an actuality entailment in the past tense and the perfective. ${ }^{21}$ (Bhatt 1999: 188) "There seems to be a class of verbs which behave like implicative verbs in the perfective and attribute ability in the presence of genericity." In the case of dé in LAC, it rather seems to be disposition which is attributed to dé than ability, according to the agentivity constraint proposed in Bhatt. The implicative reading of dé is discussed under 3.4.

Opportunity implies that barriers are temporarily released and allow the agent of the complement verb to perform the situation; usually without any temporal restrictions with regard to past-tense contexts. (Xie 2012: 391). Opportunity belongs to the category of circumstantial possibility and it designates, "a property of an individual or entity anchored to the context in which the individual/entity is." (Xie 2012: 391) ${ }^{22}$ With dé, the enabling conditions are frequently mentioned. In the examples in (26), the enabling conditions are not directly expressed; however, dé clearly displays an opportunity reading. In all instances, dé can be rendered by 'have/had the opportunity to'. In the first clause of (26a), the enabling conditions, in this case a participant-internal ability expressed by néng, are revealed. The enabling conditions in (26b) and (26c) are provided in the preceding context. (26c) and (26d) show that the opportunity to perform $x$ can function as the condition for subsequent events.

(26) a. 「... 然不自意能先入關破秦, 得復見將軍於此。(shijii: 7,312) (EMC) rán_bù_zì_yì_néng_xiān_rù_guān_pò_Qín_

but_NEG_self_think_able.to__before_enter_pass_destroy_Qin__

dé_fù_jiàn_jiàngjūn__yú_cǐ

DE_again_see__general_at_this

... but I do not think myself that I am able to enter the gate and destroy Qin, and to be able to see the general again here.

b. 僕得聞此, 不忘於心。願君之亦勿忘也。」(zhànguó cè 20) (LAC-EMC) Pú_dé_wén_cǐ_bù_wàng_yú_xīn_yuàn_jūn_zhī_yì_wù_wàng_yě Servant_DE__hear_this_NEG_forget_PREP_heart_Wish_prince_SUB_ also_NEGmod_forget__SFP

After I could hear this, I will not forget it in my heart. I wished that you would also not forget it.

\footnotetext{
${ }^{21}$ Bhatt (1999: 187): "Sentences like 'John was able to lift the truck' are ambiguous between a 'managed to' implicative verb-like reading which asserts that John actually lifted the truck and says nothing about John's abilities and a 'had the ability to' reading which asserts that John has the ability to lift the truck." Thus, "The implicative verb reading is only available in non-generic (perfective) environments, while the 'had the ability to' reading is only available in generic (imperfective) environments."

${ }^{22}$ This reading goes back to Austin 1970 (Xie 2012: 391).
} 
c. 若寡人得沒于地, 天其以禮悔禍于許, 無寧茲許公復奉其社稷,

Ruò_guă_rén_dé_mù_yú_dì_tiān_qí_yř_lǐ_huǐ_huò_yú_Xǔ

If_lonely_man_DE_die_PREP_soil_heaven_MOD_YI_rites_regret_m

isfortune_PREP_Xu

wúnìng_z $\overline{\mathbf{z}} \_$_Xǔ_gōng_fù_fèng_qí_shèjì

rather_this_X $\mathrm{Xu} \_$duke_again__present__his__gods.of.earth.and.grain

If I am able to die in the land, and if Heaven would according to the rites regret the misfortunes inflicted on Xu, would then the duke Xu not rather present offerings again to his gods of earth and grain? (zuǒzhuàn, yin 11) (LAC)

d. 我等每自思惟: 『設得受記, 不亦快乎。』」(taishō 9, n. 262, p.29b) (late EMC)

Wǒ_děng_měi_zì_sīwéi_shè_dé_shòu_jì_bù_yì_kuài_hū I_PL_each_self_think_if__DE_receive_promise_NEG__MOD_delightful SFP

Whenever we think by ourselves, if we could receive the promise to attain nirvana, would that not be delightful!

In (27) the enabling conditions are referred to by the demonstrative pronoun $c \check{l}$ 此 'this' or by the phrase rú/ruò č̀ 如/若此 'like this, thus'. In (27a, b), they are revealed in the preceding narrative. In (27c), they are mentioned in the first clause. In (27a), the complement verb is a verb of perception; this implies a low degree of agentivity; in (27b) and (27c), the subject is clearly agentive. In (27d), it is [-HUMAN] and non-agentive.

(27) a. 此臣之日夜切齒腐心也, 乃今得聞教！」(shǐji: 86,2533) (EMC)

Cì_chén_zhī_rì_yè_qiè_chǐ_fŭ_xīn_yě_năi_jīn__dé_wén_jiào This_subject_SUB_day_night_champ_tooth_spoil__heart_SFP_then_ now_DE__hear_teaching

Therefore, I champ my teeth and grieve in my heart day and night, and thereupon I am now able to hear the instructions.

b. 此幸臣之所以得欺主成私者也。(hán fēiž 14/1/5) (LAC)

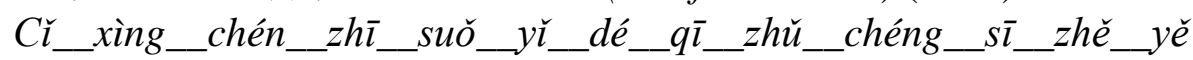

This_favour_subject_GEN_REL_Y Y__DE_cheat_ruler_achieve__

personal.advantage_REL_SFP

This is how favoured subjects manage to cheat their rulers and achieve their own personal advantages.

c. 如此則太后心安，君等幸得脫禍矣。」(shiji: 9;399) (EMC)

Rú_cì_zé_tàihòu_xīn_ān_jūn_děng_xìng_dé_tūo__huò_yǐ

Like_this_then_Queen.dowager_heart_secure_prince_group_luck_DE_ remove_misfortune_SSP

Like this, the Queen dowager will feel secure and you and your party will be lucky enough to be able to remove misfortune.

d. 若此則能順其天，意氣得游乎寂寞之宇矣，形性得安乎自然之所矣。

Ruò_cǐ_zé_néng_shùn_qí_tiān_yì_qì_dé_yóu_hū_jí_

mó zhī yǔ yř

If_this_then_can_follow_POSS_heaven_mind_energy_DE_float_PREP

_quiet_calm_SUB_world_SFP

__xíng__xìng__dé_ān__hū_zìrán_zhī_suǒ_yǐ

__form_emotion_DE__peaceful_PREP_natural_GEN_place_SFP 
Being like this, he is then able to follow his heaven[ly destiny], his mind and energy are able to float in a world of calm and silence, his shape and emotions are able to dwell in peace in a place of naturalness. (lǘshì chūnqiū 17/1/4/8) (LAC)

\subsection{Implicative reading of the auxiliary verb dé}

In past tense and perfective contexts, dé has an implicative reading; an actuality entailment is implied in a conventional implicature somewhat similar to 'manage to'. Many of the requirements for implicative verbs are met by dé. These are, 1) Implicatives take VP complements, 2) The subject of the implicative verb and of the verbal complement must be identical, 3) Adverbial modification must have the same effect on the complex VP as on the complement VP, 4) Implicative applies to active verbs and with stative verbs they have a marked meaning, 5) Implicatives are tense and aspect dependent (perfective aspect). A further argument for the analysis of dé as an implicative verb comes from the fact that the auxiliary verb dé 'manage to, able to' has developed from a verb with the meaning 'obtain, get'; both the verbs 'get' and 'manage to' appear in the list of implicative verbs in Kartunnen (1971: 341, 350). The opportunity meaning of 'get' is captured by Karttunnen's paraphrase of the meaning of 'get' (1971: 351) "get to do depends on the chance to get to do." The implicative reading establishes a sub-group of the opportunity - or ability - reading of dé. In the following examples, the possible situation expressed by the modal predicate has been actualized. In the examples (28a) and (28b), temporal sequence is marked in the second clause by the temporal conjunctions 遂 suì 'then, thereupon' and 乃 năi 'then, thereupon'. But this does not necessarily imply that the situation is located in the past. In (28c), temporal sequence from past to speech time is marked by the predicate zhi jin 'arrive at the present point in time'. Additionally, the past setting of the respective events in $(28 \mathrm{a}-\mathrm{d})$ is induced by the context the examples appear in. In (28e) and (28f) (repeated from example (23) above), the past situation is explicitly marked by past denoting or perfective adverbs.

(28) a. 克舍之, 丑父遂得亡歸齊。 (shiji: 32,1497) (EMC)

Kè_shě_zhī__Chǒufù_suì_dé_wáng__guī_Qí

$\mathrm{Ke}$ _release_OBJ_Choufu_thereupon_DE_flee_return_Qi

Ke released him, and Choufu (managed thereupon to) could thereupon flee and return to Qi.

b. 楚軍大亂, 壞散, 而漢王乃得與數十騎遁去, (shiji: 7,322) (EMC)

Chŭ_jūn_dà_luàn_huài_sàn_ér_Hàn_wáng

Chu_army_great_chaos__break.apart_scatter_CON_Han_king__

năi_dé_yŭ_shù_shí_qí_dùn_qù

then_DE__with_several_ten__horseman_flee_go.away

The army of Chu was in great chaos, broke apart and was scattered, and so the King of Han could / managed to flee with thirty or forty horsemen, ...

c. 足下所以得須舆至今者, 以項王尚存也。(shiji: 92,2622) (EMC)

Zúxià_suǒyǐ_dé_xūyú_zhì_jīn_zhě_y̌̀_Xiàng_wáng_shàng_cún_yě Sir_therefore_DE_temporarily_arrive_today_REL_because_XXiang_King _ _still_exist_SFP

Sir, the reason why you were able to / have managed to get to the present point for the time being is because King Xiang is still there.

d. 行十七日計可千五百里。得至鄯鄯國。(taishō 51, n. 2085, p.857a) (EMC) Xíng_shí_qī_rì_jì_kě_qiān_wǔ_bǎi_lǐ_dé_zhì_Shànshàn_guó Travel_ten_seven_day_calculate_POSS_tousand_five_hundred_mile_ DE_arrive_Shanshan_state 
They travelled seventeen days and calculated that it was about one thousand five hundred miles when they managed to arrive at the state Shanshan.

e. 『舜往于田，則吾既得聞命矣; (mèngzǐ 5.1.1) (LAC)

Shùn_wăng_yú_tián_zé_wú_jì_dé_wén_mìng_yǐ

Shun_wander_PREP_field_then_I_JI_DE_hear_mandate_SFP

That Shun wandered around in the fields, I already managed to understand its meaning, ...

f. 未嘗得聞社稷之長計。(zhànguó cè 19) (LAC-EMC)

Wèi_cháng_dé_wén__shèjí_zhī__cháng_jì

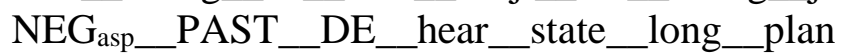

I never before managed to/could hear about long-range plans for the state.

\subsection{Deontic DE}

Deontic readings with the possibility modal dé first emerge in LAC and EMC in polarity contexts, i.e. in rhetorical questions and negated contexts (Liu 刘利 2000, Li 李明 2001). The deontic reading is logically implied, because NEG MODposs 'not possible that $p \neg \nabla p$ is equivalent with 'necessary that not $p \square \neg p$ ' in terms of necessity (Meisterernst 2020b). Dé allows both a possibility and a deontic (necessity) reading. Meisterernst (2020b) proposes an analysis of the semantic scope of negation as evidence for different syntactic positions in which the deontic and possibility readings of MODposs in LAC and EMC are interpreted, following a proposal in Cormack and Smith (2002). The development of dé into the deontic modal déi 'must' of Modern Mandarin is supposedly the result of this early ambiguity of reading of MODposs in polarity contexts. ${ }^{23}$ In (29a), dé evidently has a possibility reading, the negator scopes over the modal; in (29b) and (29c), the negator is in the scope of the modal, which thus receives a deontic interpretation.

(29) a. 我等梵天所化。是以無常。不得久住。(agama, T01, 1, p. 69b) (late EMC) Wǒ_děng_fàntiān_suǒ_huà_shìy̌__wúcháng_bù_dé_jiǔ_zhù I_PL_Brāhma_REL_change_therefore_impermanent_NEG_DE_long_stay $\overline{W e}$ are who go $\bar{d}$ Brahm $\bar{a}$ changed, therefore we don't have permanence and cannot remain long.

Paraphrase: we do not manage to remain long = NoT [POSSIBLE: circumstantial.

b. 明主之道, 臣不得以行義成榮, 不得以家利為功。(hán fēiž̌ 48/8/3) (LAC)

Míng_zhǔ_zhī_dào_chén_bù_dé_yǐ_xíng_yì_chéng_róng

Enlighten_ruler_GEN_way_minister_NEG_DE_YI_carry.out

righteousness_achieve_glory

bù_dé_y̌̀_jiā_lì_wéi_gōng

NEG_DE_YI_house_advantage_make_merit

According to the way of an enlightened ruler, the ministers may not achieve glory with just carrying out righteousness, and they may not gain merit by advantages for their families.

Paraphrase: it is necessary that they do not achieve glory..., that they do not gain merit by $=$ NECESSARY [NOT

c. 時優婆夷, 聞佛世尊, 正由我故, 制諸比丘, 不得食肉, (Xianyujing T4, 202, p. 375c) (late EMC)

Shí_yōupóyí_wén_fó__shìzūn

Time_upāsika_ask__Buddha_World-Honoured-One,

\footnotetext{
${ }^{23}$ Due to the lack of space, this development is not related in detail in this discussion; the focus is rather on the the semantics of DE as a condition for its development as a postverbal modal. The reader is referred to Meisterernst (2020b).
} 
zhèng_yóu_wǒ_gù_zhì_zhū_bǐqiū_bù_dé_shí_ròu correct_from_I__reason_determine_PL_bhiksū_NEG_DE_eat_meat

At the time a laywoman asked the Buddha: "World-Honoured-One, did you make these corrections because of me and determined that the bhiksū may not to eat meat." Paraphrase: it is mandatory that bhiksū does not eat meat $=$ NECESSARY[NOT

\subsection{Concluding remarks on the modal auxiliary verb dé}

The examples in this section demonstrated that the auxiliary verb dé can have ability, disposition, and opportunity readings. In past tense contexts dé has an implicative reading, thus it shows semantic similarities to able to, and manage to in English. The implicative reading can be derived from the semantics of $d e$ as a lexical verb with the meaning 'get, obtain'. The ability and the disposition readings are the least frequent readings of dé in the periods under consideration; they show a strong tendency to have a generic reading. The opportunity reading is the predominant reading of the modal auxiliary verb dé; it underlies all other readings; the subject of the modal predicate can be agentive or non-agentive. Deontic readings are present, but require particular syntactic constraints related to polarity. Both the possibility (potential) reading and the deontic (permissive) reading proposed for postverbal Cantonese DAK in Cheng and Sybesma (2004) are attested for the preverbal modal dé in EMC, suggesting that the paths of grammaticalization of pre- and postverbal DE were to a certain extent similar semantically. In a modal predicate with dé, the thematic features of the subject depend on the argument structure and the syntax of the complement verb and not on dé. Beside its function as a modal auxiliary verb, dé prevails as a lexical verb throughout the LAC and EMC periods. Similar to many other modals in Chinese, it is subject to a lexical split into a lexical and a functional category. This is the typical scenario for Chinese modals.

\section{The development of postverbal DE}

In Late Archaic and Early Middle Chinese, the complement of the modal verb dé can be either a tenseless, non-finite $v \mathrm{P}$ as in example (30a) and the examples above, or it can be a CP. In the latter case, dé still has full lexical status. An argument for the CP analysis of the complement of dé is the fact that deontic negative markers can appear in its complement as in $(30 \mathrm{~b}, \mathrm{c})$. Deontic negative markers are necessity operators, which have been proposed to appear in the CP/TP layer above possibility modals (Meisterernst 2020b, based on Cinque 1999, Tsai 2015). ${ }^{24}$ In any case, as deontic modals, they have to be analyzed as appearing above $v \mathrm{P}$. If $d e ́$ were analyzed as a modal auxiliary verb expressing possibility in (30b) and (30c), this would lead to the irregular order possibility necessity (Meisterernst 2020a, b, see also below). In (30a), the epistemic adverb bì 必 and the future marker dāng 當 precede dé; the complement is a simple VP. (30b) and (30c) represent the two modal negative markers wú 無 and wú 冊 in the complement of dé, which argue for the CP status of the complement of $d e^{25}$

(30) a. 我等亦如是，必當得作佛。(taishō 9, n.262, p.12a) (late EMC)

Wǒ_děng yì rú_shì bì dāng_dé zuò fó

1P_PL_also_like_this_certainly_F $\overline{\mathrm{UUT}} \_\overline{\mathrm{DE}} \_$be_Buddha

... we are also like that and will certainly manage to become Buddhas.

b. 此彈丸之地, 猶不予也, 令秦來年復攻王, 得無割其內而媾乎? 」

Cǐ__dànwán_zhī_dì̀_yóu__bù_yǔ_yě_líng__ín_lái_nián_fù_gōng__ wáng__

\footnotetext{
${ }^{24} \mathrm{Li}$ (2015: 163) proposes that these negative markers have imperative force and are probably generated in the $\mathrm{CP}$ layer.

${ }^{25}$ Djamouri (1991) proposes an epistemic reading for wú 冊.
} 


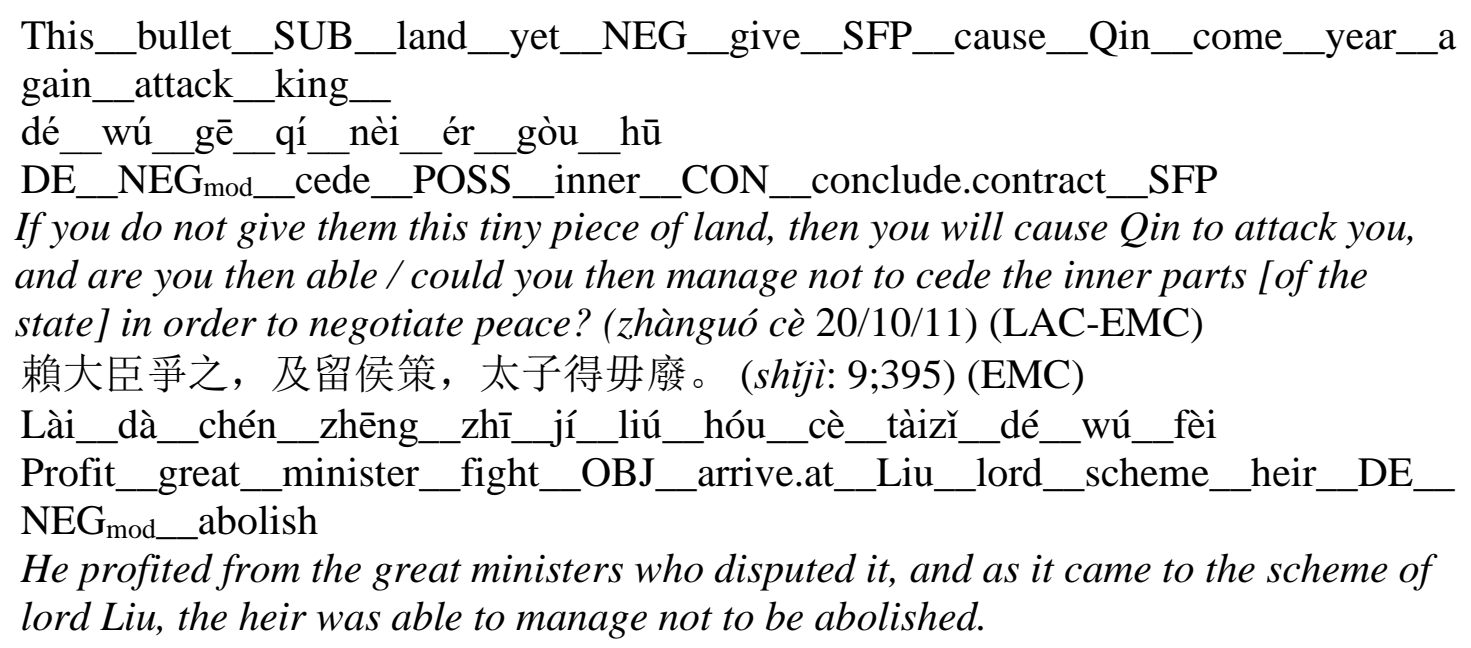

The complement of dé can also be a full (probably finite) clause; the subject has nominative case as in example (31). In LAC, embedded non-finite clauses usually have genitive subjects; the embedded clause is nominalized. In middle Chinese, the case distinction has disappeared (Aldridge 2013) and embedded clauses are not nominalized anymore.
婆羅門作是說。言。此我不得名斷滅。(taishō 1, n.1, p.93a) (late EMC)
Póluómén_zuò_shì_shuō_yán_cľ_wǒ_bù_dé_míng_duànmiè
Brāhman_make_this_speech_say_this____NEG__DE_name_eradicate
The brāhman made the following speech and said: This means that I do not succeed [in the attempt] that my name is being eradicated.

The behavior of dé in the examples discussed in this section argues for two different instantiations of dé: 1) as an auxiliary verb, similar to the semi-modal 'able to/manage to' in English with a clear implicative reading in past contexts, and 2) as a lexical (modal) verb with a semi-modal meaning which allows a CP complement to follow. It is this syntactic ambiguity, which allows two different developments of modal dé as a preverbal deontic modal verb and as a postverbal resultative marker.

According to Wang 王力 (2004: 350), the basis of postverbal DE, i.e. dé as a $\mathrm{V}_{2}$ first appears during the Han period, in the Early Middle Chinese period. During this period, it still clearly functions as a verb in its lexical meaning 'gain, obtain, achieve', referring to the successful achievement of the event expressed by the preceding verb. This is not different from other resultative verb constructions that make their appearance during this period. This is shown in the two examples in $(32 \mathrm{a}, \mathrm{b})$; in both examples dé is not followed by a $v \mathrm{P}$ or CP complement. (31c) is one of the earliest examples, in which $\mathrm{V}_{1}+\mathrm{DE}$ is followed by a $v \mathrm{P}$ or $\mathrm{CP}$, and where $\mathrm{DE}$ has to be analyzed as a functional category introducing a result (Wu 吳福祥 2004: 153) and not as a resultative verb anymore. In this example, DE had lost its semantic content and its argument structure and it is reduced to the expression of the resultative. Examples like this demonstrate that DE first had to lose its argument structure before it could grammaticalize into a postverbal functional category (see also Wu 吳福祥 (2004: 150f).
(32) a. 民採得，日重五銖之金，一色正黃。(lùnhéng 19.58) (EMC) mín_căi__dé_rì_chóng_wǔ_shú_zhī_jīn_y people_gather_get_day_double_five__shu__GEN__metal_one_appearance_ _real_yellow
People gather and obtain, and they daily double five shu of metal, it is monochrome and of a true yellow color.


b. 若道術不可學得, 則變易形貌, (bàopǔzľ, nèipiān duìsú 3) (EMC)

Ruò_dào_shù_bǔ_kě_xué_dé_zé_biànyì_xíngmào

If_Dao_art_NEG_can_learn__get_then_change_appearance

If the magic art of the Dao cannot be learned and obtained, then one changes the appearance ...

c. 迷得襄王抛國位 (DHBW 8.7) (MC)

Mí dé Xiāng wáng pāo guó wèi

Bewitch DE Xiang king cast.aside state position

King Xiang was bewitched so that cast aside his state position.

Structures like those in the examples (32a) and (32b) pave the way for constructions with an intransitive resultative $\mathrm{V}_{2}$, in which the two verbs do not constitute an object sharing construction anymore; they are still extremely infrequent in EMC. These structures are allegedly the basis for the development of postverbal $\mathrm{DE}$, when a $v \mathrm{P}$ or a $\mathrm{CP}$ introducing a result attaches to them. Even in Middle Chinese there are hardly any examples, in which $\mathrm{V}_{1}+\mathrm{DE}$ is followed by a $\mathrm{CP}$ or $v \mathrm{P}$, and which allow an analysis of $\mathrm{DE}$ as a postverbal modal marker. The example in (32c) from the vernacular Dunhuang bianwen literature (cf. Wu 吳福祥 2004: 153) is one of the earliest unambiguous instances. The number of instances only increases after the Middle Chinese period, and in the $13^{\text {th }} \mathrm{c}$. in Early Mandarin postverbal DE is well attested (Feng 馮春田 1992). The analysis of this development and a syntactic analysis of the grammaticalization of postverbal DE go beyond the scope of the present analysis; they are the topic of a separate study (Meisterernst $2019 \mathrm{~b}(\mathrm{~ms}).){ }^{26}$

\section{Conclusion}

The analysis of the lexical semantics and the argument structure of dé shows that it is a typical achievement verb in its intransitive, but also in its transitive use. In the transitive construction, it by default has a [+HUMAN] goal subject, no ACT or CAUSE event are included in the event template of dé: [BECOME $[\mathrm{y}<\operatorname{STATE}=\operatorname{GET} / \operatorname{OBTAIN}(E D)>]]$.

The basic function of dé as a modal auxiliary verb is to express opportunity readings. From this reading, the infrequent ability and disposition readings, but also the deontic readings dé can receive in particular syntactic environments can be derived. The sensitivity of dé to perfective marking together with its semantics as an achievement verb qualify it as typical implicative verb; it shows implicative readings in past and perfective contexts similar to the implicative verb manage to in English. Most of the functions proposed for postverbal DE in Xie (2012) are already present in the modal auxiliary verb dé. However, postverbal DE has probably developed from the semi-lexical achievement verb dé, expressing a result, and not from the modal auxiliary verb dé.

\footnotetext{
${ }^{26}$ I am very grateful to one of the anonymous reviewers for pointing out the significance of statistical studies in order to provide evidence for different stages of grammaticalization. However, this method has not been applied in this study for mainly two reasons. The most relevant reason is that the topic of the paper is the analysis of the lexical semantics and particularly the argument structure of dé in history as a basis for further studies of the development of the two instantiations of DE, the preverbal and the postverbal one, in Modern Sinitic languages. We tried to show to which extent the semantics of both pre-, and post-verbal DE were already present in LAC. We also proposed that the early grammaticalization into a deontic marker concerned preverbal DE in polarity contexts and that the basis of the emergence of postverbal DE was the split of preverbal DE from the lexical verb GET, OBTAIN. Preverbal DE followed the common path of grammaticalization of all modals in Chinese, whereas the lexical verb dé increasingly developed into a resultative marker, over time allowing a CP complement in its argument structure. The second reason for not applying the statistical method is that instances showing this development were very infrequent throughout the Middle Chinese period and only became more frequent from the $10^{\text {th }} \mathrm{c}$. on. This period is not subject of the present study.
} 
The paper tentatively proposes that, syntactically, the two different functions of modal DE in Modern Mandarin, i.e. the function as a deontic modal auxiliary verb děi , and the function as a postverbal modal marker of manner and result, derive from two different instantiations of $d e ́$ in EMC. The deontic marker děi derives from the modal auxiliary verb dé, which is characterized by a non-finite $v \mathrm{P}$ complement. The postverbal modal marker DE derives from the semi-modal lexical verb dé, which has a (finite) $\mathrm{CP}$ complement. The particular syntactic constraints of the achievement verb dé, which contrast it to the other modal verbs of possibility in LAC, triggers the split between auxiliary dé and postverbal DE and its grammaticalization into a marker of the resultative and of manner. However, more research has to be conducted on the diachronic development of dé to confirm this hypothesis.

\section{References}

Abraham, Werner and Elisabeth Leiss. 2008. Modality-aspect interfaces: implications and typological solutions. Amsterdam/ Philadelphia: John Benjamins Pub. Co.

Alexiadou, Artemis and Florian Schäfer(eds.). 2013. Non-canonical passives. Amsterdam: John Benjamins.

Alexiadou, Artemis. 2014. Active, middle, and passive: the morphosyntax of Voice. Catalan Journal of Linguistics 13:1-22.

Aldridge, Edith. 2013. Chinese Historical Syntax: Middle Chinese. Language and Linguistics Compass: Historical Linguistics 7(1):39-57.

Aldridge, Edith. 2015. Pronominal Object Shift in Archaic Chinese. In Syntax over Time: Lexical, morphological and information-structural interactions, ed. Theresa Biberauer and George Walkden, 350-370. Oxford: Oxford University Press.

Aldridge, Edith and Barbara Meisterernst. 2018. Resultative and termination: A unified analysis of Middle Chinese VP-YI. In Topics in Theoretical Asian Linguistics, eds. Kunio Nishiyama, Hideki Kishimoto, and Edith Aldridge, 157-179. John Benjamins.

Austin, John Langshaw. 1970. Ifs and cans. In Austin philosophical papers, ed. G.O. Urmson and G.J. Warnock, 205-233. New York: Oxford University Press.

Baxter, William H. and Laurent Sagart. 2014. Old Chinese reconstructions. Available at http://ocbaxtersagart.lsait.lsa.umich.edu/BaxterSagartOCbyMandarinMC2014-0920.pdf. Accessed 25 May 2018.

Bassac, Christian and Pierrette Bouillon. 2002. Middle Transitive Alternations in English: A Generative Lexicon Approach. In Many Morphologies, eds. Paul Noucher and Marc Plenat. Somerville, 29-47. MA: Cascadilla Press.

Bhatt, Rajesh. 1999. Covert modality in non-finite contexts. PhD dissertation, University of Pennsylvania.

Bresnan, Joan. 2001. Lexical-Functional Grammar. Oxford: Blackwell.

Cheng, Lisa Lai-Shen and Sybesma Rint. 2004. Postverbal 'can' in Cantonese (and Hakka) and Agree. Lingua 114:419-446.

Cinque, Guglielmo. 1999. Adverbs and Functional heads: A Crosslinguistic Perspective. Oxford: OUP.

Cormack, Annabel and Neill Smith. 2002. Modals and Negation in English. In Modality and its Interaction with the Verbal System, Linguistik Aktuell 47 / Linguistics Today 47, ed. Sjeg Barbiers, Frits Beukema, Wim van der Wurff, 133-163. Amsterdam: John Benjamins.

Cruse, D. Alan. 1973. Some thoughts on Agentivity. Journal of linguistics 9:11-23.

Djamouri, Redouane. 1991. Particules de négation dans les inscriptions sur bronze de la dynastie des Zhou [Particles of negation in the Zhou dynasty bronze inscriptions]. Cahiers de Linguistique Asie Orientale 20(1):5-76. 
Djamouri, Redouane. 1999. Evolution of zhi in Archaic Chinese. In In Honor of Mei Tsu-Lin : Studies on Chinese Historical Syntax and Morphology, ed. Alain Peyraube and Sun Chaofen, 33-48. Paris : EHESS.

Dobson, William Arthur Charles Harvey. 1959. Late Archaic Chinese: a grammatical study. Toronto: Toronto University Press.

Dölling, Johannes and Tatjana Heyde-Zybatow. 2007. Verb Meaning: How much Semantics is in the Lexicon? In Interface and Interface Conditions, ed. Andreas Späth, 33-75. Berlin: Mouton De Gruyter.

Downer, Gordon B. 1959. Derivation by tone-change in classical Chinese. Bulletin of the School of African and Oriental Studies 22(2):258-290.

Dowty, David. 1991. Thematic Proto-Roles and Argument Selection. Language 67(3):547619.

Fagan, Sarah. 2009. The Syntax and Semantics of Middle Constructions. ( $2^{\text {nd }}$ edition) Cambridge: Cambridge University Press.

Feng, Shengli. 2014. Light verb syntax between English and Classical Chinese. In Chinese Syntax in a Cross-linguistic Perspective, ed. Audrey Li, Andrew Simpson and WeiTien Dylan Tsai, 229-250. Oxford: Oxford University Press.

Feng, Chuntian 馮春田. 1992. Analysis of the main employments of 'de', 'le', 'zhe' in “Zhu zi yulei” “朱子語類” “得” ， “了’ ， “着”的主要用法分析. In Investigation of the Chinese language of the Song, Yuan, and Ming periods 宋元明漢語研究, ed. Cheng Xiangqing 程湘清, 243-288. Shandong: Shanddong jiaoyu chubanshe.

Gabelentz, Georg von der. 1960. Chinesische Grammatik, Mit Ausschluss des Niederen Stiles und der Heutigen Umgangssprache [Chinese Grammar: Under exclusion of the Low Style and the Contemporary Vernacular Language]. Halle: Niemeyer, (1881) 1960.

Hackl, Martin. 1998. On the semantics of “ability attributions”. Ms, MIT.

Hale, Kenneth and Samuel Jay Keyser. 2002. Prolegomenon to a Theory of Argument Structure. Cambridge: MIT Press.

Heine, Berndand Tania Kuteva. 2019. World Lexicon of Grammaticalization. Cambridge: CUP.

Huang, James C.-T., Y.-H. Audrey Li, and Yafei Li. 2009. The Syntax of Chinese. Cambridge: Cambridge University Press.

Haudricourt, André G. 1954. Reconstruire le chinois archaïque [Reconstruction of Archaic Chinese]. Word 10(2-3):351-364.

Jin, Lixin 金理新. 2006. A study of old Chinese morphology 上古汉语形态研究. Hefei: Huangshan Publishing House.

Karlgren, Bernhard. 1933. Word families in Chinese. Bulletin of the Museum of Far Eastern Antiquities 5: 9-120.

Karttunen, L. 1971. Implicative Verbs. Language 47(2):340-358.

Kratzer, Angelika. 1996. Severing the External Argument from its Verb. In Phrase Structure and the Lexicon, ed. Johan Rooryck and Laurie Zaring, 101-137. Dordrecht: Kluwer.

Lekakou, Marika. 2005. In the Middle, Somewhat Elevated: The Semantics of Middles and its Crosslinguistic Realization. Ph.D. dissertation, University of College London.

Levin, Beth. 1993. English Verb Classes and Alternations: A Preliminary Investigation. Chicago: University of Chicago Press.

Levin, Beth and Malka Rappaport Hovav. 1995. Unaccusativity. Cambridge, MA: MIT Press. $\mathrm{Li}$, Ming 李明. 2001. The historical development of Chinese modal auxiliary verbs 漢語助動 詞的歷史發展. Ph.D. dissertation. Beijing: Peking University.

Li, Yin. 2015. The Diachronic Development of Passive Constructions from Archaic Chinese to Modern Mandarin. PhD thesis. Seattle: University of Washington. 
Liu, Li 刘利. 2000. A study of modal auxiliary verbs in Pre-Qin Chinese 先秦漢語助動詞研 究. Beijing: Beijing Normal University Publishing Group.

Lu, Deming 陸德明 (Tang). 1985. Annotations on the Classics 經典釋文. Shanghai: Shanghai Ancient Books Publishing House.

Marelj, Marijana. 2004. Middles and Argument Structure across Languages. Utrecht: LOT.

Mei, Guang 梅廣. 2015. Outline of Classical Chinese Grammar 上古漢語語法綱要. Taipei: Sanmin.

Mei, Tsu-lin 梅祖麟. 2000. Temporal strata in derivation by the four tones 四声别义中的时 间层次. Studies of the Chinese Language 中国语文 6:427-443. Reprinted in Collection of linguistic articles by Mei Zulin 梅祖麟語言學論文集, 306-339, Beijing: The Commercial Press.

Mei, Tsu-lin 梅祖麟. 1988. Three examples of internal reconstruction in Chinese 内部拟构汉 语三例. Studies of the Chinese Language 中国语文 204(3):169-181.

Mei, Tsu-lin. 2015. Proto-Sino-Tibetan Morphology and its modern Chinese correlates. In Oxford handbook of Chinese Linguistics, eds. William S-Y. Wang and Chaofen Sun, 58-67. Oxford: Oxford University Press.

Meisterernst, Barbara. 2008a. Modal verbs in Han period Chinese Part I: The syntax and semantics of kĕ 可 and kě y̌ 可以. Cahiers de Linguistique Asie Orientale 37(1):85120.

Meisterernst, Barbara. 2008b. Modal verbs in Han period Chinese Part II: Negative Markers

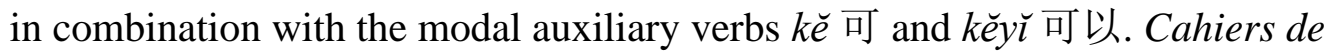
Linguistique Asie Orientale 37(2):197-222.

Meisterernst, Barbara. 2015a. Tense and aspect in Han period Chinese: A linguistic study of the 'Shiji'. Berlin: DeGruyter.

Meisterernst, Barbara. 2015b. New Issues in Chinese Grammar: The Morpho-Syntax of the Aspectual System in Late Archaic Chinese. In Studies on Folklore, Classics and Chinese Character 民俗典籍文字研究 15. Beijing: The Commercial Press.

Meisterernst, Barbara. 2016. The syntax of aspecto-temporal adverbs from Late Archaic to Early Medieval Chinese. Journal of East Asian Linguistics 25(2):143-181. DOI: 10.1007/s10831-015-9140-3.

Meisterernst, Barbara. 2017. Modality and Aspect and the Role of the Subject in Late Archaic and Han period Chinese: obligation and necessity. Lingua Sinica 3:10.

Meisterernst, Barbara. 2019a. A new approach on the modal KE 可 and the relation between the aspectual and the modal system in Archaic Chinese". In New perspectives on Aspect and Modality in Chinese Historical Linguistics Frontiers in Chinese Linguistics, ed. Barbara Meisterernst, 159-190. Springer and Peking University Press.

Meisterernst, Barbara. 2019b. The diachronic development of postverbal DE in Chinese. Paper presented at the $24^{\text {th }}$ International Conference of Historical Linguistics. Canberra, Australia.

Meisterernst, Barbara. 2020a. A new approach to the development of deontic markers: In PreModern Chinese. In A Typological Approach to Grammaticalization and Lexicalization, Trends in Linguistics, vol 327, ed. Janet Xing, 191-230. Berlin: De Gruyter Mouton.

Meisterernst, Barbara. 2020b. Possibility and Necessity and the Scope of Negation in Early Middle Chinese, Forthcoming in International Journal of Chinese Linguistics.

Peyraube, Alain. 1996. Recent issues in Chinese historical syntax. In New Horizons in Chinese Linguistics, Studies in Natural Language and Linguistics Theory, ed. C.-T. James Huang and Y.-H. Audrey Li, 161-213, Dordrecht: Springer. 
Pulleyblank, Edwin G. 1995. Outline of Classical Chinese Grammar. Vancouver: University of British Columbia Press.

Rappaport Hovav, Malka and Beth Levin. 1998. Building Verb Meanings. In The Projection of Arguments: Lexical and Compositional Factors, ed. Miriam Butt and Wilhelm Geuder, 97-134. Stanford: CSLI Publications.

Sagart, Laurent. 1999. The Roots of Old Chinese. Amsterdam/Philadelphia: John Benjamins.

Schuessler, Axel. 2007. ABC etymological dictionary of old Chinese. Honolulu, HI: University of Hawaii Press.

Tsai, Wei-Tian Dylan. 2015. On the Topography of Chinese Modals. In Beyond Functional Sequence, ed. Ur Shlonsky, 275-294. New York: Oxford University Press.

Unger, Ulrich. 1983. Hao ku 好古: Sinological Circular. Early China 9/10:169-174.

Unger, Ulrich. 1988. Grammar of Classical Chinese. Grammatik des Klassischen Chinesisch. Münster: unpublished.

van der Auwera, Johan, and Vladimir A. Plungian.1998. Modality's semantic map. Linguistic Typology 2:79-124.

Vendler, Zeno. 1967. Linguistics and philosophy, $1^{\text {st }}$ edition. Ithaca, NY: Cornell University Press.

Wang, Li 王力. 2004 (1980). Hanyu shigao. Beijing: Zhonghua Book Company.

Wei, Pei-chuan 魏培泉. 2001. New evidence on a joint discussion of fú and wù 〈「弗」、

「勿」拼合說新証〉. Bulletin of the Institute of History and Philology Academia Sinica 歷史語言研究所集刊 72(1):121-215.

$\mathrm{Wu}$ Fuxiang 吳福祥. 2004. Analysis of the grammar of 12 languages in Dunhuang bianwen 敦 煌變文集 12 種語法研究. Henan: Henan University Press.

Xie, Zhiguo. 2012. The modal uses of de and temporal shifting in Mandarin Chinese. Journal of East Asian Linguistics 21:387-420.

Xing, Janet and Axel Schuessler. 2020. Semantic extension in Old Chinese: Direction, transitivity, and voice. In Typological Regularity of Semantic Change in Grammaticalization and Lexicalization, ed. Janet Xing, 165-190. Berlin: DeGruyter.

Xiong, Jiajuan. 2017. Chinese Middle Constructions: Lexical Middle Formation. Frontiers in Chinese Linguistics. Singapore: Springer and Peking University Press.

(C2020 Barbara Meisterernst. This is an open access article licensed under the Creative Commons Attribution-NonCommercial-NoDerivs License (http://creativecommons.org/licenses/by-nc-nd/3.0/). 